\title{
Late Quaternary vegetation and climate of SE Europe - NW Asia according to pollen records in three offshore cores from the Black and Marmara seas
}

\author{
Popescu Speranta-Maria 1, *, Jimenez-Moreno Gonzalo ${ }^{2}$, Klotz Stefan ${ }^{3}$, Lericolais Gilles ${ }^{4}$, Guichard \\ François ${ }^{5}$, Cagatay M. Namik ${ }^{6}$, Giosan Liviu ${ }^{7}$, Calleja Michel ${ }^{8}$, Fauquette Séverine ${ }^{9}$, Suc Jean-Pierre

${ }^{1}$ GeoBioStratData.Consulting, 385 route du Mas Rillier, 69140 Rillieux la Pape, France

2 Departamento de Estratigrafía y Paleontología, Universidad de Granada, Avenida Fuentenueva s/n, 18002 Granada, Spain

${ }^{3}$ Forschungsbereich Geographie, Universität Tübingen, Rümelinstrasse 19-23, 72070 Tübingen,

Germany

4 IFREMER, 29280 Plouzané, France

${ }^{5}$ Laboratoire des Sciences du Climat et de l'Environnement, CNRS-CEA-UVSQ (UMR 8112), Bâtiment 714, L'Orme des Merisiers, 91191 Gif-sur-Yvette Cedex, France

6 ÝTÜ EMCOL and Geological Engineering Department, Faculty of Mining, Ayazaða, 34469 Ýstanbul, Turkey

7 Department Geology \& Geophysics, Woods Hole Oceanographic Institution, Woods Hole MA 02543, USA

${ }^{8}$ Montpellier SupAgro, 2 place Pierre Viala, 34060 Montpellier Cedex 2, France

9 ISEM, Univ. Montpellier, CNRS, IRD, EPHE, Montpellier, France

${ }^{10}$ Sorbonne Université, CNRS-INSU, Institut des Sciences de la Terre, ISTeP UMR 7193, 75005 Paris, France

*Corresponding author : Speranta-Maria Popescu, email address : speranta.popescu@gmail.com

\begin{abstract}
:
High-resolution pollen analyses were performed on two cores from the western Black Sea and one core from the Marmara Sea, covering the Late Glacial-Holocene transition using 14C chronology. Particular effort was invested in the botanical identification of pollen grains thereby significantly improving our knowledge of regional flora. When interpreted with respect to modern vegetation, pollen records revealed all the major changes caused by climatic fluctuations over the last 20,000 years. The results of this study provide evidence for the occurrence of relict thermophilous-hygrophilous trees (papillate Cupressaceae, Carya, Liquidambar, Zelkova) in certain refugia up to the Holocene. Vegetation dynamics is specified for some taxa (e.g., Cupressus-Juniperus, Fagus, Cedrus) and some ecosystems (e.g., mesophilous forests, Mediterranean sclerophyllous populations, steppes). Pollen data enabled palaeoclimatic reconstructions which were compared with available estimates in the region. The use of a powerful pollen ratio between 'thermophilous and steppe taxa' led to fruitful climatostratigraphic relationships with the oxygen isotope curve from the NGRIP core. The Younger Dryas and cooling at $8.2 \mathrm{ka}$ are among the most obvious climatic phases identified in the three cores studied here.
\end{abstract}


Keywords : Last Glacial - Holocene pollen flora, W Black Sea - Marmara Sea regions, Plant diversity, Vegetation dynamics, Climate reconstruction, Climatostratigraphy 


\section{Acknowledgements}

Contribution to the European Community Project ASSEMBLAGE (EVK3-CT-2002-00090) with the support of a Fullbright Grant (S.-M.P.) and a Von Humbold grant (S.K.). The crew and captain of the research vessel Le Suroit are acknowledged for their support in coring. M. Casas Gallego and Carina Hoorn are acknowledged for improving the manuscript with their comments and corrections. We are also grateful for the invitation to contribute to this special issue by the guest-editors Angela Bruch, Dieter Uhl and Torsten Utescher 


\section{Introduction}

Located at the crossroad of complex climate systems, the Black Sea region is today controlled by cold air masses originating from the north, the Mediterranean seasonal rhythm dominating in the south-west, and the aridity which characterises the Anatolian Plateau to the south (Fig. 1) (Peel et al. 2007; Rego and Rocha 2014). Similar compound interactions probably also prevailed in the region in past cold periods such as the Last Glacial Maximum (Arpe et al. 2011). From a physiographical point of view, today the Black Sea today is a semi-enclosed anoxic basin with major sediment inputs from the Danube River, secondary sedimentary contributions from the Dniester, Dnieper, and Sakarya rivers in its western part and to a lesser extent from smaller and less powerful rivers in its eastern part (Fig. 1) (Algan et al. 1999). During the Last Glacial, the Black and Marmara seas were disconnected from the Mediterranean Sea and evolved in brackish to freshwater conditions (Ryan et al. 1997, 2003; Major et al. 2002; Çağatay et al. 2000, 2015). Evidence for reconnection with the Mediterranean Sea is the deposition of sapropels resulting from high organic productivity and water-column stratification leading to the development of anoxic conditions on the sea floor (see Çağatay et al. 2019 and references herein). The base of each sapropel is a chronostratigraphic layer. In the Marmara Sea, the sapropel is dated $10,600{ }^{14} \mathrm{C}$ yr BP at the base and $6,400{ }^{14} \mathrm{C}$ yr BP at the top (Çağatay et al. 2000, 2015, 2019; Mudie et al. 2001, 2002, 2004; Aksu et al. 2002; Caner and Algan, 2002). In the Black Sea, the sapropel has a generally accepted age of 7,160 ${ }^{14} \mathrm{C}$ yr BP at the base and $3,330{ }^{14} \mathrm{C}$ yr BP at the top (Jones and Gagnon 1994; Ryan et al. 1997; Major et al. 2002). Several proxies have been used in palaeoclimatic reconstructions of the Late Pleistocene-Holocene in the region (Major et al. 2006; Mudie et al. 2002, 2007; Londeix et al. 2009; Valsecchi et al. 2012). Among them, pollen records are considered as particularly useful for the reconstruction of vegetation changes in the region, and also help build age models of the sedimentary series.

Present-day vegetation in the study region is characterized by major differences due to strong north-south temperature and precipitation gradients. The presence of high mountains also explains vegetation diversity. However, the vegetation in the study region (Fig. 2a; Quézel and Barbero 1985; Ozenda and Borel 2000) mainly comprises mesophilous forests dominated by Quercus. Large patches of open vegetation occupy the north (CrimeanUkrainian-Russian transitional meadows to steppes) and the south of the study region (Mediterranean sclerophyllous vegetation to the west, Anatolian steppes to the south; Quézel and Médail 2003). The reliefs are host to deciduous forests with Fagus and coniferous forests with Pinus, Abies and Picea at higher elevations. Broad riparian forests (Alnus, Fraxinus, Ulmus, Salix, Populus, and locally Pterocarya) grow along the main rivers and in deltas where aquatic plants also abound. A few reduced populations of Cedrus inhabit the montane belt in the Pontic Ranges (Quézel and Médail 2003).

The contrast became more marked in the study area during the glacial-interglacial successions because of increased competition between mesophilous forest ecosystems (i.e., populated with mesothermal taxa which require some humidity, including riparian, and Mediterranean sclerophyllous plants), steppe vegetation and altitudinal forests according to early-late Quaternary pollen records of the region (Wijmstra and Groenhart 1983; Tzedakis 1993; Kotthoff et al. 2008a; Bordon et al. 2009; Lézine et al. 2010; Popescu et al. 2010; Bertini et al. 2016; Miebach et al. 2016). The succession from the Last Glacial Maximum to the Holocene Interglacial in the region is documented by five long continental pollen records (Tenaghi Philippon in Northern Greece: Wijmstra and Groenhart 1983; Pross et al., 2015; Ioannina in Northwest Greece: Tzedakis 1993; Lake Maliq in Albania: Bordon et al. 2009; two records from Lake Ohrid p.p. in Albania and the Republic of Macedonia: Lézine et al. 2010; Bertini et al. 2016; Wagner et al. 2019). All these previous records suggest that the Last Glacial Maximum was characterised by the development of steppe vegetation and other 
herbaceous plants, in contrast to during the Holocene, when the vegetation was dominated by mesophilous forest trees. The Late Glacial was characterised by alternations of the two abovementioned vegetation environments (forest vs. steppe). However, these long records inform us about areas located relatively far from the Black Sea and some records concern different physiographic areas such as intra-mountain basins. Similar vegetation succession is also documented in other marine and terrestrial archives characterised by not particularly detailed pollen floras (Mudie et al. 2002, 2007; Kotthoff et al. 2008a,b; Valsecchi et al. 2012; Miebach et al. 2016). Changes in the late Quaternary vegetation around the Black Sea are thus poorly documented.

The southern and south-eastern shores of the Black Sea are considered to be present-day refuge areas for thermophilous plants (Quézel and Barbero 1985; Denk et al. 2001; Quézel and Médail 2003). A similar status is allocated to this region for the Pliocene up to the Late Pleistocene (Shatilova et al. 2011; Biltekin et al. 2015). For example, the occurrence of Glyptostrobus in the region during the Late Pleistocene and Holocene has been reported by Biltekin et al. (2015) and Richards et al. (2017) on the shorelines of the Black and Caspian seas, respectively.

The NGRIP oxygen isotope curve (ice core from North Greenland) provides a well-dated continuous record detailing climate changes during the last 120 kyrs (Vinther et al. 2006, Rasmussen et al. 2014, Seierstad et al. 2014) which can be correlated for climate changes in pollen records at any latitude (e.g.: Pross et al 2015).

The aim of this study was an extremely detailed analysis of pollen flora based on the botanical identification of pollen grains. This approach also enabled us to conduct a reliable climatic quantification of the pollen data.

The objectives of the paper are to answer the following questions: (1) is it the process and/or speed of climate changes that has driven regional vegetation in the last $20 \mathrm{kyrs}$, sometimes supporting the spread of forests from the Danube and Dniester plains and/or from the southern Black Sea shore, and sometimes the spread of open vegetation from the northern plains and/or from the Anatolian Plateau? (2) how did the passage from prevalent steppe vegetation to prevalent forests and back take place? (3) how did thermophilous relicts indicated by Biltekin et al. (2015) behave in response to climatic vicissitudes? (4) how did Mediterranean sclerophyllous communities survive in the area and expand during the Holocene? (5) in how much detail can the climatic changes be quantified and compared to the NGRIP reference oxygen isotope curve?

\section{Material and methods}

${ }^{14} \mathrm{C}$ dating was performed on shells in BLKS9810 and C10 cores (Table 2). The results are given in years BP, but were not calibrated because of the difficulties involved in attributing reasonable radiocarbon reservoir ages in the Black Sea and Marmara Sea basins (Ryan 2007; Fontugne et al. 2009; Soulet et al. 2011; Çăgatay et al. 2015).

Pollen analysis was performed under high chronologic resolution in BLKS9810 and B2KS33 cores which were retrieved during the BLaSON 1 and BLaSON 2 cruises, respectively, and in $\mathrm{C} 10$ core, which is in the İstanbul Technical University EMCOL core repository (Fig. 1; Table 1). A total of 155 samples from BLKS9810 (core length: $755.5 \mathrm{~cm}$ ) were analysed, 90 samples from B2KS33 (core length: $99 \mathrm{~cm}$ ) and 73 samples from C10 (core length: $399.5 \mathrm{~cm})$.

The sediment was chemically processed using a standard method (Cour 1974): acid attacks $\left(\mathrm{HCl}\right.$ - twice, $\mathrm{HF}$ ) to eliminate carbonates and silicates, pollen was treated with $\mathrm{ZnCl}_{2}$ (at density $=2)$ for density separation and sieving $(10 \mu \mathrm{m})$. Residues were mounted in glycerol and a little space was left between the slide and the cover slip to allow limited movement of 
the mounting liquid by exerting pressure with a tiny toothpick; the movement allowed the pollen grains to be rotated and consequently to examine the grains from different sides.

Pollen grains were identified and counted (up to more than 150 per sample, except Pinus which may have been more abundant). As we were able to move the grains and view them from all the sides, particular attention was paid to pollen morphology, and more than 150 taxa were identified (almost equally distributed between trees and herbaceous plants including shrubs), which significantly increased the total number of recognized plants (Tables $1-3$ in Supplementary Material) compared to previously published pollen floras in the region, which listed fewer than 30 taxa (Mudie et al. 2002, 2007; Caner and Algan 2002; Valsecchi et al. 2012; Miebach et al. 2016). For example, the papillate pollen of Cupressaceae (formerly 'Taxodiaceae') was not distinguished in the previously mentioned studies or, when identified, was been erroneously considered as reworked.

To test the reliability of the resulting pollen data with respect to vegetation, assuming that the correspondence was also true in the past, we compared the present day vegetation with 14 recent pollen floras (Fig. 2; Table 4 in Supplementary Material) obtained from 11 surface samples from Black and Marmara cores (less than 1,000 years old) and three from whipped up dust (including airborne pollen grains mostly from the local vegetation) trapped in filters in a car driven along pathways (Figs. 2A, 2-3). This method, developed by Cour (1974), provides pollen floras that can be directly correlated with the present-day plant inventory.

Complete pollen data from the marine cores are provided in Tables 1-3 in Supplementary Material and illustrated by synthetic diagrams in which the taxa are grouped according to their ecological significance (Figs. 3-5). The ecological groups mainly follow Nix's (1982) classification based on mean annual temperature (MAT): megathermal (tropical) taxa: MAT $>24^{\circ} \mathrm{C}$; mega-mesothermal (subtropical) taxa: $20^{\circ} \mathrm{C}<\mathrm{MAT}<24^{\circ} \mathrm{C}$; mesothermal (warmtemperate) taxa: $14^{\circ} \mathrm{C}<\mathrm{MAT}<20^{\circ} \mathrm{C}$; meso-microthermal (cool-temperate) taxa: $12^{\circ} \mathrm{C}<\mathrm{MAT}<14^{\circ} \mathrm{C}$; microthermal (boreal) taxa: MAT $<12^{\circ} \mathrm{C}$. An additional summary plot was obtained by using a ratio between two opposite groups of palaeoclimatic proxy taxa, i.e. not influenced by the other taxa (Cour and Duzer 1978). Accordingly, a pollen ratio was calculated between the thermophilous taxa (i.e., the mega-mesothermal plus mesothermal taxa: listed in Table 3) and the steppe taxa (listed in Table 3), showing opposing palaeoclimatic behaviour throughout the records. The ratio is less than ' 1 ' when the number of steppe vegetation pollen grains is higher than the number of thermophilous taxa, and the ratio is higher than '1' when the reverse is the case. As previously shown by Suc et al. (2018), the curve obtained from this pollen ratio can be correlated with any reference oxygen isotope curve. The major and secondary phases of dominant steppe pollen (i.e., ratio $<1$ ) are correlated with the long cold and short and relatively cold phases of the NGRIP curve, respectively (Fig. 6). Conversely, the major and secondary phases of dominant pollen of thermophilous elements (i.e., ratio $>1$ ) are correlated with the long warm and short relatively warm phases of the NGRIP curve, respectively (Fig. 6). These correlations are, of course, proposed within the time frame defined by the ${ }^{14} \mathrm{C}$ ages (see the 'Chronology' section below and Figs. 3-5).

A variety of quantitative climate reconstructions based on late Quaternary biological proxies was reviewed by Birks et al. (2010), including 'probability mutual climatic spheres' (PCS) (Klotz et al. 2003, 2004). Basically, this method calculates the climatic range of a fossil flora using the mutual climatic ranges of the individual taxa in the past flora. Specifically, this is done by using 2-dimensional spheres, plotting the taxa's requirements e.g. the mean temperature of the warmest month versus the mean temperature of the coldest month. The intervals of the related climate parameters are derived from the mutual climatic sphere of the past flora. To obtain more precise palaeoclimate information, probability intervals within the mutual ranges are calculated which rely on the comparison of the fossil intervals with a multitude of intervals of present-day floras (Klotz et al. 2003, 2004). The principle of the 
method implies that the reconstruction is independent of the existence of modern analogue floras since only the presence of taxa is considered (at a level of $0.5 \%$ abundance), but not their specific combinations. The quality of the method was previously tested based on a large number of present-day floras (Klotz et al. 2003), yielding information on the correlation between reconstructed and actual climate values (mean average errors are $1.1^{\circ} \mathrm{C}$ for summer temperatures, $1.7^{\circ} \mathrm{C}$ for winter temperatures, $1.1^{\circ} \mathrm{C}$ for mean annual temperature, and $100 \mathrm{~mm}$ for mean annual precipitation).

The pollen slides are housed at the Geobiostratdata laboratory.

\section{Results}

Our results first concern new ${ }^{14} \mathrm{C}$ datings, that completes the chronology of the cored sediments. We then document the representativeness of modern pollen floras in terms of present-day vegetation. We describe the pollen records from the three cores and interpret them as changes in vegetation, with respect to the major vegetation phases and their potential age according to the available ${ }^{14} \mathrm{C}$ chronology. Finally, we present climate quantification from pollen records.

\section{Chronology}

In the Marmara Sea core C10, the sapropel is present at a depth of between 200 and $80 \mathrm{~cm}^{1}$. Our radiocarbon dating $\left(13,625 \pm 115{ }^{14} \mathrm{C}\right.$ yr BP $)$ is consistent with the age assigned by Çağatay et al. (2015) (Fig. 5). The age $16,300 \pm 100{ }^{14} \mathrm{C}$ yr BP we obtained from the lowermost layers of the core completes the chronology (Fig. 5). In this sedimentary archive, the end of the Last Glacial Maximum and the Late Glacial are probably recorded below the sapropel indicating the beginning of the Holocene. In the BLKS9810 core, the sapropel is present at a depth of between 40 and $16 \mathrm{~cm}$ and its age is consistent with our radiocarbon dating at $10,640 \pm 80,11,410 \pm 110$ and $12,790 \pm 110{ }^{14} \mathrm{C}$ yr BP, respectively (Fig. 3). The age $17,760 \pm 130{ }^{14} \mathrm{C}$ yr BP we obtained from the lower layers of the core completes the chronology. In this sedimentary archive, the end of the Last Glacial Maximum and the Late Glacial are probably also recorded below the sapropel, which was deposited during the Early Holocene. In the B2KS33 core, the sapropel is present at a depth of between 24 and $1 \mathrm{~cm}$, and is the only chronological information available in the core (Giunta et al. 2007).

\section{Representativeness of pollen floras}

Pollen records obtained from whipped up dust were collected in three well-known plant populations: a low altitude deciduous forest dominated by Quercus cerris, a mid-altitude mixed forest dominated by Fagus sylvatica, Acer and Betula just below the Picea belt, and a high altitude evergreen coniferous forest dominated by Picea abies (respectively localities 1, 2 and 3 in Figure 2b and Table 4 in Supplementary Material; present-day climate is indicated in Table 4). Pollen contents from these samples (synthetic diagrams in Figure 2b, sites 1-3; detailed pollen floras in Table 4 in Supplementary Material) are in agreement with the local vegetation. Deciduous Quercus was dominant in the arboreal pollen flora at location 1, followed by riparian taxa. Fagus was dominant in the arboreal pollen flora at location 2, followed by deciduous Quercus, with some influence of Abies and Picea pollen originating from the overlying vegetation belt. At location 3, Picea and Abies were dominant, followed by Fagus, deciduous Quercus, Alnus and Betula pollen grains transported from lower vegetation belts. Similar amounts of Pinus pollen were found at all three locations, which is consistent with the presence of this conifer in different vegetation belts. Pollen grains of

\footnotetext{
${ }^{1}$ All the depths provided in the paper are in $\mathrm{cm}$ below the sea floor.
} 
herbaceous plants (mostly Poaceae, Urticaceae and Plantago) were similarly abundant at all three locations, underlining the importance of understorey plants.

Pollen grains recorded in marine surface sediments of the Black Sea (localities 4-13 in Figure 2a) must be considered as mostly transported by the rivers flowing into its western part. The same pollen grains recorded in the Marmara Sea (locality 14 in Figure 2a) must be considered as almost exclusively transported by air because of the relatively low riverine input in this basin. All the surface sediments overlie the sapropel layer and are consequently less than 1,000 years old (synthetic diagrams in Figure 2b, sites 4-14; detailed pollen floras in Table 4 in Supplementary Material). Pinus pollen grains are often abundant as they are easily transported. Overall, these pollen records are dominated by mesothermal taxa (deciduous Quercus, Carpinus, etc.) together with herbaceous taxa (including from the steppe). The complexity of the vegetation is also reflected in the significant contribution of high altitude taxa (Fagus, Abies, Picea) and of Mediterranean sclerophyllous plants (Olea, Quercus ilex type). The notable role of river transport is also indicated by numerous pollen grains of riparian trees and aquatic plants. Except in core C10, pollen of some relict taxa has rarely been recorded in the other two cores studied. These taxa include papillate Cupressaceae, Liquidambar cf. orientalis, Carya, and Zelkova. Liquidambar and Zelkova today grow not far from the study area (for details see: Biltekin et al. 2015). We examined them under fluorescence light and can confirm that they have been not reworked. Papillate Cupressaceae and Carya have been recorded among the last surviving thermophilous-hygrophilous relict plants in the region and some studies suggest that their extinction was probably due to human activities (Biltekin et al. 2015; Richard et al. 2017). The present-day climate of the southern Black Sea shorelines is temperate and humidity is almost continuous throughout the year: MAT: $9-15^{\circ} \mathrm{C}$; mean annual precipitation (MAP): $600-1200 \mathrm{~mm} / \mathrm{yr}$ (Table 4). This climate suits Carya (MAT between 2 and $5^{\circ} \mathrm{C}$ in North America; Thompson et al. 2000) and Glyptostrobus (which survives today in China and Vietnam under MAT ranging from $10.6^{\circ} \mathrm{C}$ to $23^{\circ} \mathrm{C}$ and MAP ranging from 950 to $2148 \mathrm{~mm} / \mathrm{yr}$; Fang et al. 2011).

Vegetation changes during the last 20,000 years

The synthetic diagrams of the BLKS9810, B2KS33 and C10 cores clearly show significant changes in the pollen records which, in the chronological frame provided by ${ }^{14} \mathrm{C}$ radiocarbon dating, reflects changes in the vegetation due to different climatic conditions (Orombelli and Ravazzi 1996) and enabled the rough climatic subdivision shown in Figures 3-5. In the following, we focus on the vegetation dynamics during three main periods of the last 20,000 years.

Last Glacial Maximum (Figs. 3-5; Tables 1-3 in Supplementary Material)

During the Last Glacial Maximum, which is considered to end at about 15,000 yr BP (Orombelli and Ravazzi 1996), the vegetation was similar according to all three cores studied (core depths: BLKS9810: 755.5-264 cm; B2KS33: 99-72.5 cm; C10: 399.5-300 cm). The marked expansion of open vegetation throughout the region is indicated by the abundance of herbaceous plants (mainly Asteraceae, Amaranthaceae, Caryophyllaceae, Cyperaceae, Poaceae, and Rumex) and steppe taxa (mainly Artemisia, and more rarely Ephedra and Hippophae rhamnoides). Steppe taxa were more abundant in the B2KS33 record maybe because it was cored in the southwestern deep basin of the Black Sea which was less influenced by river transport of arboreal pollen grains and instead was subject to Anatolian influence. Previous studies showed that herbaceous plants are generally under-represented in pollen floras (Favre et al. 2008), supporting our interpretation of very open landscapes at regional scale. The contribution of mesothermal trees was relatively small (mainly deciduous Quercus, Carpinus, Corylus, and components of riparian populations such as Ulmus, Zelkova, 
Alnus, Salix, Populus, Fraxinus, Carya, Pterocarya and Liquidambar). These ecosystems could have occurred in disconnected refuge areas, such as along rivers, lakes and the seashore. Some relic mega-mesothermal taxa (Glyptostrobus for example) could have also been present in these arboreal refugia. These relicts were not found in the B2KS33 record. Their absence can be explained by the great distance of the core site from the shore as cause of their dilution in the most abundant and higher transport-effective tree pollen taxa. In contrast, their occurrence is higher in the C10 record maybe because of the short distance between the core site and the Marmara Sea shore. Aquatic and Mediterranean ecosystems were probably limited in extent. A similar conclusion can be drawn concerning the mesomicrothermal and microthermal communities, the geographic extent of which was probably very reduced because of the spread of herbaceous plants. Cupressus-Juniperus appear to have gained strength as pioneers during short episodes of steppe decline. Today, these Cupressaceae constitute pre-steppe pioneer assemblages in the Turkish Peninsula (Quézel and Médail 2003). Thermophilous and hygrophilous taxa were somewhat more frequent at the end of the Last Glacial period, indicating a relative increase in arboreal populations in contrast to open landscapes. Pinus pollen was relatively abundant. It is impossible to conclude if Pinus contributed to one or several ecosystems as we were unable to identify it at the sub-genus level.

\section{Late Glacial (Figs. 3-5; Tables 1-3 in Supplementary Material)}

This study shows that the Late Glacial (core depths: BLKS9810: 264-88 cm; B2KS33: 72.5$48.5 \mathrm{~cm}$; C10: 300-198 cm) can be subdivided into three climatic phases: two cooling periods (Oldest Dryas and Younger Dryas) separated by a warmer period (Bølling/Allerød). The Oldest Dryas is estimated to have ended at about 13,000 yr BP, and the Younger Dryas to have started at about 11,000 yr BP (Orombelli and Ravazzi 1996). The Oldest and Younger Dryas are clearly marked by increasing amounts of pollen from herbaceous plants including steppe taxa in the BLKS9810 and B2KS33 cores, while the Bølling/Allerød episode, characterised by a decrease in herbaceous and steppe taxa and the expansion of mesothermal trees, is more distinct in the B2KS33 and C10 cores. The Younger Dryas is more distinct than the Oldest Dryas in the $\mathrm{C} 10$ core. The Bølling was not clearly distinguishable from the Allerød in any of the three records.

The Oldest Dryas (core depths: BLKS9810: 264-159 cm; B2KS33: 72.5-68.5 cm; C10: $300-287 \mathrm{~cm}$ ) showed almost the same palynological characteristics as the lower part of the Last Glacial Maximum except for the difference in the tree redistribution at its end.

The Bølling/Allerød (core depths: BLKS9810: 159-113 cm; B2KS33: 68.5-52.5 cm; C10: $287-242 \mathrm{~cm}$ ) was mainly distinguishable thanks to the decrease in herbaceous and steppe taxa and a marked increase in Pinus, which partially masked the increase in mesothermal trees, especially in the BLKS9810 and C10 cores. The increase in Abies (microthermal tree), recorded in the same cores, may result from reorganisation of the arboreal belts with the redistribution of conifers in altitudinal environments due to climate warming. Evergreen Quercus (i.e., sclerophyllous Mediterranean species represented by the Quercus ilex pollen type) increased somewhat in core B2KS33, perhaps linked to the recovery of the coastal areas of the southern Black Sea by these populations.

The Younger Dryas (core depths: BLKS9810: 113-88 cm; B2KS33: 52.5-48.5 cm; C10: $242-198 \mathrm{~cm}$ ) is characterised in all three records by an abrupt return to glacial-like conditions with evidence for a marked decrease in thermophilous-hygrophilous trees and a significant increase in herbaceous plants including steppe taxa. Open vegetation recovered large spaces at the regional scale. The $\mathrm{C} 10$ record suggests that Cupressus-Juniperus populations continued to thrive during this short episode. 
Holocene (Figs. 3-5; Tables 1-3 of the Supplementary Material)

The Holocene (core depths: BLKS9810: 88-0 cm; B2KS33: $48.5-0 \mathrm{~cm}$; $\mathrm{C} 10: 198-0 \mathrm{~cm}$ ) is formally subdivided into three stages (Walker et al. 2019). The Early (11,700-8,200 cal yr BP) and the Middle Holocene (8,200-4,200 cal yr BP) can be considered as more or less equivalent to the Preboreal, Boreal and Atlantic climate phases based on changes in the vegetation according to palynology, with ages at their base estimated at 10,200, 9,000, and $8,000 \mathrm{yr}$ BP, respectively (Beaulieu et al. 1994). The three phases are clearly recorded in cores B2KS33 and C10. The Atlantic Phase can also be differentiated in core BLKS9810 but the subdivision between Preboreal and Boreal phases is not clear and probably occurred in the 88-40 $\mathrm{cm}$ interval. The base of the Atlantic Phase coincides with the base of the sapropel dated 7,160 $\mathrm{yr} \mathrm{BP}$ in cores BLKS9810 and B2KS33. This suggests that condensed sedimentation may correspond to the beginning of the Atlantic chronozone.

The Preboreal Phase (core depths: B2KS33: 48.5-33.5 cm; C10: 198-129 cm) was initially characterised by increasing biodiversity among the mesothermal taxa while the amount of pollen of steppe and other herbaceous plants decreased significantly. An increase in Fagus was visible in both records. Abies and evergreen evergreen Quercus increased slightly at this time. Cupressus-Juniperus are present in larger quantities in the B2KS33 record. Cedrus is sporadically recorded in core $\mathrm{C} 10$.

The Boreal Phase (core depths: B2KS33: 33.5-24.5 cm; C10: 129-90 cm) is indicated by a slight decrease in mesothermal taxa correlated with an increase in herbaceous plants in the B2KS33 core, and a marked decrease in mesothermal taxa correlated with a proportional increase in steppe and other herbaceous taxa in core C10. Fagus was still present in the two records at this period but more abundantly in core B2KS33. Evergreen Quercus showed similar abundances in the two cores. Abies was present in core $\mathrm{C} 10$.

The Atlantic Phase (core depths: BLKS9810: 40-0 cm; B2KS33: 24.5-0 cm; C10: 90-0 cm) is marked by a sharp increase in thermophilous and hygrophilous taxa and a marked decrease in steppe and other herbaceous taxa. The vegetation reached its modern organisation in the region at this time: herbaceous landscapes were probably displaced to the north of the Black Sea, steppe ecosystems confined to the Anatolian Plateau, mesophilous forests developed at low elevation everywhere, meso-microthermal and microthermal tree populations were restricted to the reliefs, and sclerophyllous Mediterranean assemblages settled along the Aegean coast (evergreen Quercus and Olea: core C10) and in a few locations along the south Black Sea coastline (evergreen Quercus: cores BLKS9810 and B2KS33). Plant diversity in mesophilous forests increased particularly in riparian taxa around lakes and rivers. These forests still included some relict mega-mesothermal taxa, which were particularly wellrepresented in core C10. Fagus spread remarkably during this period, especially in core B2KS33 where it displayed two maxima. Abies was represented more abundantly in B2KS33 and $\mathrm{C} 10$ records, in association with Picea in the BLKS9810 core. Cupressus-Juniperus were less represented than earlier.

Climate quantification from pollen records

Climatic parameters were quantified for the BLKS9810 and C10 pollen records (Figs. 3 and 5). The results obtained in the two archives are almost the same. During the Last Glacial Maximum, the mean annual temperature (MAT) ranged between $+5^{\circ} \mathrm{C}$ and $+10^{\circ} \mathrm{C}$, the mean temperature of the coldest month (MTC) between $-5^{\circ} \mathrm{C}$ and $+2^{\circ} \mathrm{C}$ and the mean temperature of the warmest month (MTW) between $+14^{\circ} \mathrm{C}$ and $+20^{\circ} \mathrm{C}$. Mean annual precipitation (MAP) fluctuates between 500 and $1000 \mathrm{~mm} / \mathrm{yr}$ during the same period. The Oldest Dryas was marked by lower temperatures, especially a MTW plateau at $+15^{\circ} \mathrm{C}$, and marked variation in MAP amplitude (300-800 mm/yr). The Bølling/Allerød, which cannot be clearly subdivided based on pollen content, is made up of two phases based on temperature: a warmer period 
$\left(+7^{\circ} \mathrm{C}<\mathrm{MAT}<+10^{\circ} \mathrm{C},-2.5^{\circ} \mathrm{C}<\mathrm{MTC}<+1^{\circ} \mathrm{C},+15^{\circ} \mathrm{C}<\mathrm{MTW}<+20^{\circ} \mathrm{C}\right)$ followed by a short and cooler period $\left(+6^{\circ} \mathrm{C}<\mathrm{MAT}<+9^{\circ} \mathrm{C}\right.$, MTC dropped to ca. $-6^{\circ} \mathrm{C}$ and MTW to $\left.+14{ }^{\circ} \mathrm{C}\right)$. Precipitation indicates more humid conditions with MAP $>700 \mathrm{~mm} / \mathrm{yr}$. In contrast, the Younger Dryas was significantly colder $\left(+6^{\circ} \mathrm{C}<\mathrm{MAT}<+9^{\circ} \mathrm{C}, \quad-5^{\circ} \mathrm{C}<\mathrm{MTC}<-2^{\circ} \mathrm{C}\right.$, $\left.+14^{\circ} \mathrm{C}<\mathrm{MTW}<+18^{\circ} \mathrm{C}\right)$ and drier $(500<\mathrm{MAP}<600 \mathrm{~mm} / \mathrm{yr})$. The Preboreal Phase was characterised by MAT around $+9^{\circ} \mathrm{C}$, MTC around $0^{\circ} \mathrm{C}$, MTW around $+17^{\circ} \mathrm{C}$, and MAP between 600 and $1000 \mathrm{~mm} / \mathrm{yr}$. The Boreal Phase was somewhat cooler and drier (MAT decreased to $+6^{\circ} \mathrm{C}$, MTC to $-3^{\circ} \mathrm{C}$, MTW to $+16^{\circ} \mathrm{C}$, MAP to $900 \mathrm{~mm} / \mathrm{yr}$ ). During the Atlantic Phase, warm and more humid conditions prevailed $\left(+7^{\circ} \mathrm{C}<\mathrm{MAT}<11^{\circ} \mathrm{C},-5^{\circ} \mathrm{C}<\mathrm{MTC}<+4^{\circ} \mathrm{C}\right.$, $+16^{\circ} \mathrm{C}<\mathrm{MTW}<+22^{\circ} \mathrm{C}, 600<\mathrm{MAP}<1100 \mathrm{~mm} / \mathrm{yr}$ ).

These values are indicative for the whole region, but temperatures may have been $2-3^{\circ} \mathrm{C}$ lower between the Marmara shores (the source of the pollen grains recorded in core C10) and the northwestern Black Sea shore (the source of the pollen grains recorded in core BLKS9810) for a latitudinal distance of about $5^{\circ}$. In addition, a difference of $200 \mathrm{~mm} / \mathrm{yr}$ may exist between the two source areas of pollen floras, the Marmara area being less humid than the northwestern Black Sea area.

\section{Discussion}

In a nutshell, the vegetation development during the last 20,000 years can be summarised as the alternation of thermophilous taxa (mainly trees) during warm periods with herbaceous (including steppe) taxa during cold periods. However, this simplification needs to be completed with information concerning forests on the one hand and open vegetation types (Mediterranean sclerophyllous ecosystems, steppes, aquatic populations) on the other.

We already mentioned the ecological niche of Cupressus-Juniperus as pioneer trees (Miebach et al. 2016) contributing to the forest reconquest during the cold-warm climate transitions. The shorelines of the Black and Marmara seas were refuge environments for some mega-mesothermal taxa such as Glyptostrobus, Engelhardia and Nyssa during the Pleistocene glaciations up to the Holocene (Biltekin et al. 2015). This was especially true for the Marmara Sea region (see Fig. 5), probably because its temperatures were higher than in the Black Sea area (see above). Human activities thus probably explain the subsequent disappearance of these trees from the region. During cold events, the remaining mesophilous arboreal communities, that repopulated the lowlands during each warmer phase, preceded the so-called present-day 'Pontic' forests growing along the southern and south-eastern Black Sea shorelines (Quézel and Barbero 1985; Denk et al. 2001; Quézel and Médail 2003), although they lost some hygrophilous taxa after the Atlantic Phase (i.e. Carya, Parrotia, Liquidambar, Zelkova). Some of these taxa (Parrotia, Liquidambar, Zelkova) persisted in nearby particularly humid regions (Denk et al. 2001; Quézel and Médail 2003). Today, despite its decline, Cedrus libani is widely distributed in central and especially in southern Anatolia but only a few reduced communities persist on the back slope of the Pontic Ranges (Quézel and Médail 2003). The pollen of this genus is very rarely recorded in the three cores studied here. This suggests that since the Last Glacial, the status of cedar in the region of Black and Marmara seas has been almost the same as it is today. Finally, Fagus deserves some discussion with respect to its behaviour in the pollen records studied and in its modern systematics. The history of Fagus was similar in the three cores: rarely recorded in the Last Glacial, it increased during the Preboreal - Boreal phases and abounded in the Atlantic Phase, especially in the B2KS33 core. Regarding the geographic location of the cores and the abovementioned respective origins of their pollen content, the homogeneity in the Fagus record shows that today's populations in the Pontic Ranges and the south Marmara region and those of the Carpathians Mountains were established in the same way and at the same time (Fig. $2 a)$. Systematics of the genus was somewhat complex with two close subspecies, $F$. sylvativa 
subsp. sylvatica occupying the European realm and $F$. sylvatica subsp. orientalis occupying the Asian realm (Quézel and Médail 2003) up to the demonstration of the occurrence of only one species, F. sylvatica, subject to a geographical gradient (Denk 1999a, b; Denk et al. 2002).

Mediterranean sclerophyllous plants are mainly represented in the Black Sea records by Quercus ilex type (i.e., evergreen oak) and from the Last Glacial on, were almost continuously accompanied by sporadic Olea. This suggests that the southern shorelines of the Black Sea may have served as a refuge area for evergreen oaks during the Last Glacial and deglaciation. Today, these shorelines are still occupied by some scattered Mediterranean sclerophyllous communities (Quézel and Barbero 1985). Quercus ilex type is recorded continuously in the Marmara core C10 since the Last Glacial, periodically together with Olea. This association presages the vegetation growing on the Marmara coastlines today (see also: Valsecchi et al. 2012), which represents the northe-eastward expansion of the Aegean mesoMediterranean sclerophyllous vegetation (Ozenda and Borel 2000; Quézel and Médail 2003). The widespread expansion of Artemisia steppes over almost all Europe and Eurasia during the Northern Hemisphere glacial phases has long been proven (Hammen et al. 1971; Van Zeist and Bottema 1982; Shatilova et al. 2011). But the Artemisia species that contributed to this invasion have not been identified. At first sight, the Anatolian steppes, currently associated with arid and cold to very cold climatic conditions (Quézel and Médail 2003), may be considered as the appropriate source of the Artemisia invasion around the Black and Marmara seas. However, a more accurate insight should result from the ongoing study of several Artemisia pollen grains from the Last Glacial sediments compared with a database of 121 modern species and the use of scanning electronic microscopy (e.g., Suc et al. 2004). For example, most of the Last Glacial Artemisia pollen from Lake Ohrid can be identified as the modern microthermal species A. alpina inhabiting - among others regions - the Caucasus and Balkans (Suc unpublished). The aquatic ecosystems are weakly represented in the pollen records studied here. The aquatic assemblage is mainly composed of Potamogeton, Sparganium, Typha and Myriophyllum. Aquatic pollen grains are more frequent in the BLKS9810 core, probably because of the vicinity of the Danube Delta, and were controlled by changes in sea level.

Temperatures in the region (Figs. 3, 5) were significantly lower during the Last Glacial Maximum than are today (Table 4). Apart from the southern Black Sea coast, precipitation in the study area was almost the same as today. This is also true for the other cold phases. From the Preboreal episode, temperatures approached present temperatures and precipitation on the southwestern Black Sea resembles the precipitation today. The lag in temperature and precipitation development between cores BLKS9810 and C10 has already been mentioned, and probably corresponds to a climatic difference between the two regions (Northwestern Black Sea shorelines and Marmara Sea shorelines, respectively). There are very few climate quantifications based on pollen data that can be compared with our records at regional scale. The Last Glacial at Lake Ohrid was characterised by significantly lower temperatures and less precipitation (Bordon 2009; Wagner et al. 2019) than the Black and Marmara sea regions, which may be explained by elevation (700 $\mathrm{m}$ asl.) of the locality. Reconstructed temperatures at Lake Maliq (elevation: $820 \mathrm{~m}$ asl.) for the Oldest and Younger Dryas differ from our estimates but reconstructed annual precipitation does not (Bordon et al. 2009). On the contrary, temperatures and precipitation at Lake Maliq for warmer intervals (Bølling/Allerød and Preboreal) appear to have been more homogenous (Bordon et al. 2009) and comparable to our estimates. Our reconstructed temperature and precipitation values are consistent with those proposed for the Eski Acigöl crater lake in Central Turkey during the same time-interval based on geochemical data (Jones et al. 2007). It should be noted that our temperature estimates for the Last Glacial Maximum are also consistent with those obtained in climate 
model simulations for the region, but precipitation does not appear to be lower in the palaeoclimatic models (Arpe et al. 2011).

The pollen ratio of thermophilous to steppe taxa has precise climatic significance and can be successfully compared to other palaeoclimatic proxy records such as the marine and ice-core oxygen isotope curves (Suc et al. 2018). Accordingly, Figure 6 compares this ratio for the three pollen records and the NGRIP curve over the last 20,000 years (Vinther et al. 2006, Rasmussen et al. 2014, Seierstad et al. 2014). The ratio of thermophilous to steppe taxa varies considerably in the $\mathrm{C} 10$ and B2KS33 records, less in the BLKS9810 record. Values over ' 1 ' reveal the prevalence of the thermophilous taxa and are interpreted as warm periods, those below ' 1 ' the prevalence of steppe taxa and are interpreted as cold periods. However, it will be recalled that herbaceous plants are still under-represented in the pollen records (Favre et al. 2008). Comparison of the thermophilous/steppe plant curves with the NGRIP curve allows long-distance climatostratigraphic correlations which, in addition, make it possible to (1) specify the climatic stratigraphy assigned at first glance to the pollen records (Figs. 3-5), and (2) establish a global chronology to the vegetation and climate changes recorded in the present study (Fig. 6). Four types of climatic episodes are shown in Figure 6: a long cold phase (i.e., glaciation), the short relatively cold episodes (i.e., stadials), the short relatively warm episodes (i.e., interstadials), and a long warm phase (i.e., interglacial). The Last Glacial and the Younger Dryas, correlated respectively with the NGRIP GS-2.1a and GS-1 events, are well-differentiated episodes in the three pollen curves. However, the upper limit of the Last Glacial in the three thermophilous/steppe plant curves is somewhat lower in Figure 6 than in Figures 3-5 so it can be correlated with the GRIP GI-1e warm episode, representing the relatively warm interval which preceded the Oldest Dryas. The relatively warm interval sandwiched between the Last Glacial and the Younger Dryas is subdivided into seven episodes alternating between warmer and colder conditions, and correlated with the NGRIP subdivisions of GI-1 (i.e., e, d, c3, c2, c1, b, a - from the older to the younger phases). A similar comparative analysis concerns the Holocene Interglacial and the three cooler events which occurred during its lower part (Fig. 6). Among them, the $8.2 \mathrm{ka}$ event (Johnsen et al. 2001) was undoubtedly the most prominent cooling recorded in the three cores studied here. This event is particularly apparent in core C10 probably because of the slowing down of the sedimentation rate due to the sapropel deposition $(0.28 \mathrm{~mm} / \mathrm{yr}$ versus about $0.15 \mathrm{~mm} / \mathrm{yr}$ below the sapropel). Here, the $8.2 \mathrm{ka}$ event corresponds to a slight decrease in thermophilous trees and a marked increase in steppe taxa and other herbaceous plants (Fig. 5). In addition, the reduction in the sedimentation rate explains why its suddenness is not more noticeable than the preceding Younger Dryas despite similar reconstructed climatic conditions (Fig. 5). Core C10 provides a well-identified record of the $8.2 \mathrm{ka}$ event in the region, characterised by significant differences in pollen content (see for comparison: Kotthoff et al. 2008b; Miebach et al. 2016).

\section{Conclusion}

The effort invested in the botanical identification of pollen grains from three sedimentary records from the Black and Marmara seas significantly improves our knowledge of plant palaeodiversity in the region. This study also considerably advances our understanding of vegetation dynamics during the successive climatic phases that occurred in the last $20,000 \mathrm{yr}$ $\mathrm{BP}$, which, on the whole, resulted in competition between steppe vegetation and mesophilous forests. The persistence of mega-mesothermal plant relicts in some refuge areas around the Black and Marmara seas is now documented and consequently reinforced. This study also documents the critical ecological place of Cupressus-Juniperus populations during climatic transitional phases. The comparable behaviour of Fagus on both European and Asian sides of the Black Sea supports the hypothesis of a single species (F. sylvatica) inhabiting the region. 
The mode of reconquest of coastal landscapes by the Mediterranean sclerophyllous ecosystems is now also documented. Better knowledge of past Artemisia steppes requires a serious effort in comparative pollen morphology.

Climate quantification based on the pollen data provides evidence for slight intra-regional differences in temperature and precipitation during the different climatic periods. Further, the use of the pollen ratio of thermophilous to steppe taxa made it possible to identify detailed climatostratigraphic relationships with the NGRIP $\delta^{18} \mathrm{O}$ curve and, as a consequence, to consolidate the chronology of the three cores studied here.

In the Introduction section, we emphasised the present-day situation in the Black Sea region at the crossroad of complex climate systems, which, in addition to the relief, explains the marked contrasts in vegetation. We hypothesise that a similar situation prevailed in the area during past cold periods. Our results show that all the plant ecosystems observed today in the region withstood the coldest periods such as the Last Glacial Maximum despite the invasion of steppe-like vegetation at regional scale. However, this suggests a different balance between the climate systems than today during the cold phases with a stronger influence of cold dry air masses.

\section{Conflict of interest}

The authors declare that they have no conflict of interest.

\section{References}

Aksu, A. E., Hiscott, R. N., Kaminski, M. A., Mudie, P. J., Gilleptie, H., Abrajano, T., \& Yašar, D. (2002). Late Glacial-Holocene paleoceanography of the Black Sea and Marmara Sea: stable isotopic, foraminiferal and coccolith evidence. Marine Geology, 190, 119-149.

Algan, O., Gazioğlu, C., Çağatay, M. N., Yücel, Z., \& Gönençgil, B. (1999). Sediment and water influxes into the Black Sea by Anatolian Rivers. Zeitschrift für Geomorphologie N.F., 43(1), 61-79.

Arpe, K., Leroy, S. A. G., \& Mikolajewicz, U. (2011). A comparison of climate simulations fort he last glacial maximum with three different versions of the ECHAM model and implications for summer-green tree refugia. Climate of the Past, 7, 91-114.

Beaulieu de, J.-L., Richard, H., Ruffaldi, P., \& Clerc, J. (1994). History of vegetation, climate and human action in the French Alps and the Jura over the last 15,000 years. Dissertationes Botanicae, 234, 253-275.

Bertini, A., Sadori, L., Combourieu-Nebout, N., Donders, T. H., Kouli, K., Koutsodendris, A., Joannin, S., Masi, A., Mercuri, A. M., Panagiotopoulos, K., Peyron, O., Sinopoli, G., Torri, P., Zanchetta, G., Francke, A., \& Wagner, B. (2016). All together now: an international palynological team documents vegetation and climate changes during the last $500 \mathrm{kyr}$ at Lake Ohrid (SE Europe). Alpine and Mediterranean Quaternary, 29(2), 201-210.

Biltekin, D., Popescu, S.-M., Suc, J.-P., Quézel, P., Jiménez-Moreno, G., Yavuz, N. \& Çağatay, M. N. (2015). Anatolia: a long-time plant refuge area documented by pollen records over the last 23 million years. Review of Palaeobotany and Palynology, 215, 1-22.

Birks, H.J., Heiri, O., Seppä, H. \& Bjune A.E. (2010). Strengths and weaknesses of quantitative climate reconstructions based on Late-Quaternary biological proxies. The Open Ecology Journal, 3, 68-110.

Bordon, A. (2009). Dynamique de la végétation et variations climatiques dans les Balkans au cours du dernier cycle climatique à partir des séquences polliniques des lacs Maliq et Ochrid (Albanie). PhD thesis, Université de Franche-Comté, 325 pp.

Bordon, A., Peyron, O., Lézine, A.-M., Brewer, S., \& Fouache, E. (2009). Pollen-inferred Late-Glacial and Holocene climate in southern Balkans (Lake Maliq). Quaternary International, 200, 19-30. 
Çağatay, M. N., Eriş, K. K, Makaroğlu, Ö., Yakupoğlu, N., Henry, P., Leroy, S. A. G., Uçarkus, G., Sakınç, M., Yalamaz, B., Bozyiğit, C., \& Kende, J. (2019). The Sea of Marmara during Marine Isotope Stages 5 and 6. Quaternary Science Reviews, 220, 124-141. Çağatay, M. N., Görür, N., Algan, O., Eastoe, C., Tchepalyga, A., Ongan, D., Kuhn, T., \& Kuşcu, I. (2000). Late Glacial-Holocene palaeoceanography of the Sea of Marmara: timing of connections with the Mediterranean and the Black Seas. Marine Geology, 167, 191-206.

Çağatay, M. N., Wulf, S., Sancar, Ü, Özmaral, A., Vidal, L., Henry, P., Appelt, O., \& Gasperini, L. (2015). The tephra record from the Sea of Marmara fort he last ca. $70 \mathrm{ka}$ and its palaeoceanographic implications. Marine Geology, 361, 96-110.

Caner, H., \& Algan, O. (2002). Palynology of sapropelic layers from the Marmara Sea. Marine Geology, 190, 35-46.

Cour, P. (1974). Nouvelles techniques de détection des flux et des retombées polliniques: étude de la sédimentation des pollens et des spores à la surface du sol. Pollen et Spores, 16(1), 103-141.

Cour, P., \& Duzer, D. (1978). La signification climatique, édaphique et sédimentologique des rapports entre taxons en analyse pollinique. Annales des Mines de Belgique, 7-8, 155-164.

Denk, T. (1999a). The taxonomy of Fagus in western Eurasia, 1: Fagus sylvatica subsp. orientalis. Feddes Repertorium, 110(3-4), 177-200.

Denk, T. (1999b). The taxonomy of Fagus in western Eurasia, 2: Fagus sylvatica subsp. sylvatica. Feddes Repertorium, 110(5-6), 381-412.

Denk, T., Frotzler, N., \& Davitashvili, N. (2001). Vegetational patterns and distribution of relict taxa in humid temperate forests and wetlands of Georgia (Transcaucasia). Biological Journal of the Linnean Society, 72, 287-332.

Denk, T., Grimm, G., Stögerer, K., Langer, M., \& Hemleben, V. (2002). The evolutionary history of Fagus in western Eurasia: evidence from genes, morphology and the fossil record. Plant Systematics and Evolution, 232, 231-236.

Fang, J., Wang, Z., \& Tang, Z. (Eds.) (2011). Atlas of woody plants in China. Distribution and climate. Heidelberg: Springer.

Favre, E., Escarguel, G., Suc, J.-P., Vidal, G., \& Thévenod, L. (2008). A contribution to deciphering the meaning of AP/NAP with respect to vegetation cover. Review of Palaeobotany and Palynology, 148, 13-35.

Fontugne, M., Guichard, F., Bentaleb, I. Strechie, C., \& Lericolais, G. (2009). Variations in ${ }^{14} \mathrm{C}$ reservoir ages of Black Sea waters and sedimentary organic carbon during anoxic periods: influence of photosynthetic versus chemoautotrophic production. Radiocarbon, 51(3), 969-976.

Giunta, S., Morigi, C., Negri, A., Guichard, F., \& Lericolais, G. (2007). Holocene biostratigraphy and paleoenvironmental changes in the Black Sea based on calcareous nannoplankton. Marine Micropaleontology, 63, 91-110.

Hammen, T. van der, Wijmstra, T. A., \& Zagwijn, W. H. (1971). The floral record oft he late Cenozoic in Europe. In The late Cenozoic glacial ages (pp. 391-424). New Haven and London: Yale University Press.

Johnsen, S. J., Dahl-Jensen, D., Gundestrup, N., Steffensen, J. P., Clausen, H. B., Miller, H., Masson-Delmotte, V., Sveinbjörnsdottir, A. E., \& White, J. (2001). Oxygen isotope and palaeotemperature records from six Greenland ice-core stations: Camp Century, Dye-3, GRIP, GISP2, Renland and NorthGRIP. Journal of Quaternary Science, 16, 299-307.

Jones, G. A., \& Gagnon, A. R. (1994). Radiocarbon chronology of Black Sea sediments. Deep-Sea Research I, 41(3), 531-557.

Jones, M. D., Roberts, C. N., \& Leng, M. J. (2007). Quantifying climatic change through the last glacial-interglacial transition based on lake isotope palaeohydrology from central Turkey. Quaternary Research, 67, 463-473. 
Klotz, S., Guiot, J., \& Mosbrugger, V. (2003). Continental European Eemian and early Würmian climate evolution: comparing signals using different quantitative reconstruction approaches based on pollen. Global and Planetary Change, 36, 277-294.

Klotz, S. Müller, U, Mosbrugger, V., Beaulieu, J.-L. de, \& Reille, M. (2004). Eemian to early Würmian climate dynamics: history and pattern of changes in Central Europe. Palaeogeography, Palaeoclimatology, Palaeoecology, 211, 107-126.

Kotthoff, U., Müller, U., Pross, J., Schmiedl, G., Lawson, I. T., Schootbrugge, B. van de, \& Schulz, H. (2008a). Late glacial and Holocene vegetation dynamics in the Aegean region: an integrated view based on pollen data from marine and terrestrial archives. The Holocene, 18(7), 1019-1032.

Kotthoff, U., Pross, J., Müller, U. C., Peyron, O., Schmiedl, G., Schulz, H., \& Bordon, A. (2008b). Climate dynamics in the borderlands of the Aegean Sea during formation of sapropel S1 deduced from a marine pollen record. Quaternary Science Reviews, 27, 832845.

Lézine, A.-M., von Grafenstein, U., Andersen, N., Belmecheri, S., Bordon, A., Caron, B., Cazet, J.-P., Erlenkeuser, H., Fouache, E., Grenier, C., Huntsman-Mapila, P., HureauMazaudier, D., Manelli, D., Mazaud, A., Robert, C., Sulpizio, R., Tiercelin, J.-J., Zanchetta, G., \& Zeqollari, Z. (2010). Lake Ohrid, Albania, provides an exceptional multi-proxy record of environmental changes during the last glacial-interglacial cycle. Palaeogeography, Palaeoclimatology, Palaeoecology, 287, 116-127.

Londeix, L., Herreyre, Y., Turon, J.-L., \& Fletcher, W. (2009). Last Glacial to Holocene hydrology of the Marmara Sea inferred from a dinoflagellate cyst record. Review of Palaeobotany and Palynology, 158, 52-71.

Major, C. O., Goldstein, S. L., Ryan, W. B. F., Lericolais, G., Piotrowski, A. M., \& Hajdas, I. (2006). The co-evolution of Black Sea level and composition through the last deglaciation and ist paleoclimatic significance. Quaternary Science Reviews, 25, 2031-2047.

Major, C., Ryan, W., Lericolais, G., \& Hajdas, I. (2002). Constraints on Black Sea outflow tot he Sea of Marmara during the last glacial-interglacial transition. Marine Geology, 190, 1934.

Miebach, A, Niestrath, P., Roeser, P., \& Litt, T. (2016). Impacts of climate and humans on the vegetation in northwestern Turkey: palynological insights from Lake Iznik since the Last Glacial. Climate of the Past, 12, 575-593.

Mudie, P. J., Aksu, A. E., \& Yašar, D. (2001). Late Quaternary dinoflagellate cysts from the Black, Marmara and Aegean seas: variations in assemblages, morphology and paleosalinity. Marine Micropaleontology, 43, 155-178.

Mudie, P. J., Marret, F., Aksu, A. E., Hiscott, R. N., \& Gillepsie, H. (2007). Palynological evidence for climate change, anthropogenic activity and outflow of Black Sea water during the Late Pleistocene and Holocene: centennial- to decadal-scale records from the Black and Marmara Seas. Quaternary International, 167-168, 73-90.

Mudie, P. J., Rochon, A., \& Aksu, A. E. (2002). Pollen stratigraphy of Late Quaternary cores from Marmara Sea: land-sea correlation and paleoclimatic history. Marine Geology, 190, 233-260.

Mudie, P. J., Rochon, A., Aksu, A. E., \& Gillepsie, H. (2004). Late glacial, Holocene and modern dinoflagellate cyst assemblages in the Aegean-Marmara-Black Sea corridor: statistical analysis and re-interpretation of the early Holocene Noah's Flood hypothesis. Review of Palaeobotany and Palynology, 128, 143-167.

Nix, H. (1982). Environmental determinants of biogeography and evolution in Terra Australis. In W. R. Barker \& P. J. M. Greenslade (Eds.), Evolution of the flora and fauna of Arid Australia (pp. 47-66). Freewville: Peacock Publishing. 
Orombelli, G., \& Ravazzi, C. (1996). The Late Glacial and Early Holocene: chronology and paleoclimate. Il Quaternario, 9(2), 439-444.

Ozenda, P., \& Borel, J.-L. (2000). An ecological map of Europe: why and how? ComptesRendus de l'Académie des Sciences de Paris, Sciences de la vie, 323, 983-994.

Peel, M. C., Finlayson, B. L., \& McMahon, T. A. (2007). Updated world map oft he KöppenGeiger climate classification. Hydrology and Earth System Sciences, 11, 1633-1644.

Popescu, S.-M., Biltekin, D., Winter, H., Suc, J.-P., Melinte-Dobrinescu, M. C., Klotz, S., Rabineau, M., Combourieu-Nebout, N., Clauzon, G., \& Deaconu, F. (2010). Pliocene and Lower Pleistocene vegetation and climate changes at the European scale: long pollen records and climatostratigraphy. Quaternary International, 219, 152-167.

Pross, J., Koutsodendris, A., Christanis, K., Fischer, T., Fletcher, W.J., Hardiman, M., Kalaitzidis, S., Knipping, M., Kotthoff, U., Milner, A.M., Müller, U.C., Schmiedl, G., Siavalas, G., Tzedakis, P.C., \& Wulf, S. (2015). The 1.35-Ma-long terrestrial climate archive of Tenaghi Philippon, northeastern Greece: Evolution, exploration, and perspectives for future research. Newsletters on Stratigraphy, 48(3), 253-276.

Quézel, P., \& Barbero, M. (1985). Carte de la végétation potentielle de la région méditerranéenne. 1, Méditerranée orientale. Editions du Centre National de la Recherche Scientifique, Paris (pp. 3-69).

Quézel, P., \& Médail, F. (2003). Ecologie et biogéographie des forêts du bassin méditerranéen. Paris: Elsevier.

Rego, F. C., \& Rocha, M. S. (2014). Climatic patterns in the Mediterranean region. Ecologia mediterranea, 40(1), 49-59.

Rasmussen, S. O., Bigler, M., Blockley, S. P., Blunier, T., Buchardt, S. L., Clausen, H. B., Cvijanovic, I., Dahl-Jensen, D., Johnsen, S. J., Fischer, H., Gkinis, V., Guillevic, M., Joek, W. Z., Lowe, J. J., Pedro, J. B., Popp, T., Seierstad, I. K., Steffensen, J. P., Svensson, A. M., Vallelonga, P., Vinther, B. M., Walker, M. J. C., Wheatley, J. J., \& Winstrup, M. (2014). A stratigraphic framework for abrupt climatic changes during the Last Glacial period based on three synchronized Greenland ice-core records: refining and extending the INTIMATE event stratigraphy. Quaternary Science Reviews, 106, 14-28.

Richards, K., Mudie, P., Rochon, A., Athersuch, J., Bolikhovskaya, N., Hoogendoorn, R., \& Verlinden, V. (2017). Late Pleistocene to Holocene evolution of the Emba Delta, Kazakhstan, and coastline of the north-eastern Caspian Sea: sediments, ostracods, pollen and dinoflagellate cyst records. Palaeogeography, Palaeoclimatology, Palaeoecology, 468, 427452.

Ryan, W. B. F. (2007). Status of the Black Sea flood hypothesis. In V. Yanko-Hombach, A. S. Gilbert, \& P. M. Dolukhanov (Eds.), The Black Sea Flood Question (pp. 63-88). Dordrecht: Springer.

Ryan, W. B. F., Carbotte, S. M., Coplan, J. O., O’Hara, S., Melkonian, A., Arko, R., Weissel, R. A., Ferrini, V., Goodwillie, A., Nitsche, F., Bonczkowski, J., \& Zemsky, R. (2009). Global Multi-Resolution Topography synthesis. Geochemistry Geophysics Geosystems, 10, Q03014, http://dx.doi.org/10.1029/2008GC002332.

Ryan, W. B. F., Major, C., Lericolais, G., \& Goldstein, S. L. (2003). Catastrophic flooding of the Black Sea. Annual Review of Earth and Planetary Sciences, 31, 525-554.

Ryan, W. B. F., Pitman III, W. C., Major, C. O., Shimkus, K., Moskalenko, V., Jones, J. A., Dimitrov, P., Görür, N., Sakinç, M., \& Yüce, H. (1997). An abrupt frowning of Black Sea shelf. Marine Geology, 138, 119-126.

Seierstad, I. K., Abbott, P. M., Bigler, M., Blunier, T., Bourne, A. J., Brook, E., Buchardt, S. L., Buizert, C., Clausen, H. B., Cook, E., Dahl-Jensen, D., Davies, S. M., Guillevic, M., Johnsen, S., Pedersen, D. S., Popp, T. J., Rasmussen, S. O., Severinghaus, J. P., Svensson, A., \& Vinther, B. M. (2014). Consistently dated records from the Greenland GRIP, GISP2 
and NGRIP ice cores fort he past $104 \mathrm{ka}$ reveal regional millennial-scale $\delta^{18} \mathrm{O}$ gradients with possible Heinrich event imprint. Quaternary Science Reviews, 106, 29-46.

Shatilova, I., Mchedlishvili, N., Rukhadze, L., \& Kvavadze, E. (2011). The history of flora and vegetation of Georgia (South Caucasus). Tbilisi: Georgian National Museum.

Soulet, G., Ménot, G., Lericolais, G., \& Bard, E. (2011). A revised calendar age for the last reconnection of the Black Sea to the global ocean. Quaternary Science Reviews, 30, 10191026.

Suc, J.-P., Fauquette, S., \& Popescu, S.-M. (2004). L'investigation palynologique du Cénozoïque passe par les herbiers. In R. Pierrel, \& J.-P. Reduron (Eds.), Les herbiers: un outil d'avenir. Tradition et modernité (pp. 67-87). Villers-lès-Nancy: Associaiton française pour la conservation des espèces végétales.

Suc, J.-P., Popescu, S.-M., Fauquette, S., Bessedik, M., Jiménez-Moreno, G., Bachiri Taoufiq, N., Zheng, Z., Médail, F., \& Klotz, S. (2018). Reconstruction of Mediterranean flora, vegetation and climate for the last 23 million years based on an extensive pollen dataset. Ecologia mediterranea, 44(2), 53-85.

Thompson, R. S., Anderson, K. H., \& Bartlein, P. J. (2000). Atlas of relations between climatic parameters and distributions of important trees and shrubs in North America Hardwoods. U. S. Geological Survey Professional Paper, 1650(B), 1-423.

Tzedakis, P. C. (1993). Long-term tree populations in northwest Greece through multiple Quaternary climatic cycles. Nature, 364, 437-440.

Valsecchi, V., Sánchez-Goñi, M. F., \& Londeix, L. (2012). Vegetation dynamics in the Northeastern Mediterranean region during the past $23000 \mathrm{yr}$ : insights from a new pollen record from the Sea of Marmara. Climate of the Past, 8, 1941-1956.

Van Zeist, W., \& Bottema, S. (1982). Vegetational history of the eastern Mediterranean and the Near East during the last 20,000 years. In J. L. Bintliff, \& W. Van Zeist (Eds.), Palaeoclimates, palaeoenvironments and human communities in the eastern Mediterranean region in later prehistory (pp. 277-321). Oxford: BAR International Series 133.

Vinther, B. M., Clausen, H. B., Johnsen, S. J., Rasmussen, S. O., Andersen, K. K., Buchardt, S. L., Dahl-Jensen, D., Seierstad, I. K., Siggaard-Andersen, M.-L., Steffensen, J. P., Svensson, A., Olsen, J., \& Heinemeier, J. (2006). A synchronized dating of the Greenland ice cores throughout the Holocene. Journal of Geophysical Research, 111, D13102.

Wagner, B., Vogel, H., Francke, A., Friedrich, T., Donders, T., Lacey, J.H., Leng, M.J., Regattieri, E., Sadori, L., Wilke, T., Zanchetta, G., Albrecht, C., Bertini, A., CombourieuNebout, N., Cvetkoska, A., Giaccio, B., Grazhdani, A., Hauffe, T., Holtvoeth, J., Joannin, S., Jovanovska, E., Just, J., Kouli, K., Kousis, I., Koutsodendris, A., Krastel, S., Lagos, M., Leicher, N., Levkov, Z., Lindhorst, K., Masi, A., Melles, M., Mercuri, A.M., Nomade, S., Nowaczyk, N., Panagiotopoulos, K., Peyron, O., Reed, J.M., Sagnotti, L., Sinopoli, G., Stelbrink, B., Sulpizio, R., Timmermann, A., Tofilovska, S., Torri, P., Wagner-Cremer, F., Wonik, T., \& Zhang, X. (2019). Mediterranean winter rainfall in phase with African monsoons during the past 1.36 million years. Nature, 573, 256-260.

Walker, M., Head, M. J., Lowe, J., Berkelhammer, M., Björck, S., Cheng, H., Cwynar, L. C., Fisher, D., Gkinis, V., Long, A., Newnham, R., Rasmussen, S. O., \& Weiss, H. (2019). Subdividing the Holocene Series/Epoch: formalization of stages/ages and subseries.subepochs, and designation of GSSPs and auxiliary stratotypes. Journal of Quaternary Science, 34(3), 173-186.

Wijmstra, T. A., \& Groenhart, M. C. (1983). Record of 700,000 years vegetational history in Eastern Macedonia (Greece). Revista de la Academia Colombiana Ciencias Exactas, Físicas y Naturales, 15, 87-98. 


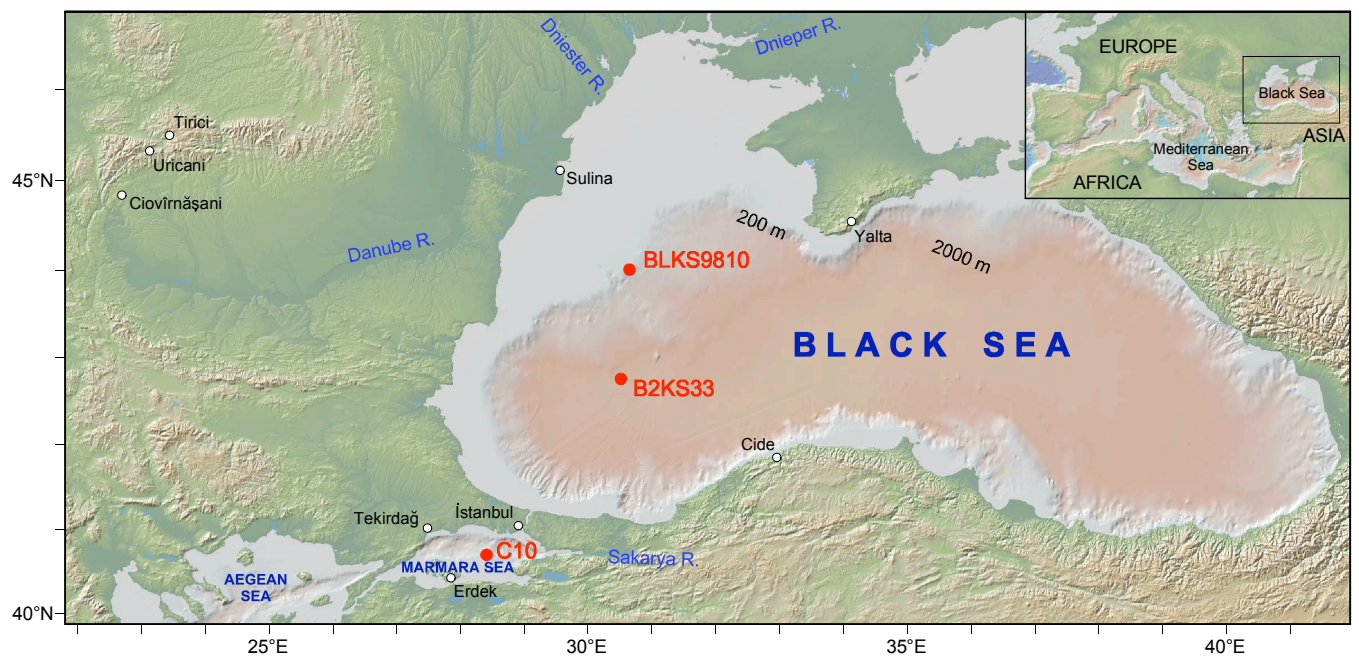

Fig. 1 Map showing the location of the studied long cores and cities of which the present-day climate is indicated in Table 4. The map is elaborated using GeoMapApp (Ryan et al. 2009).
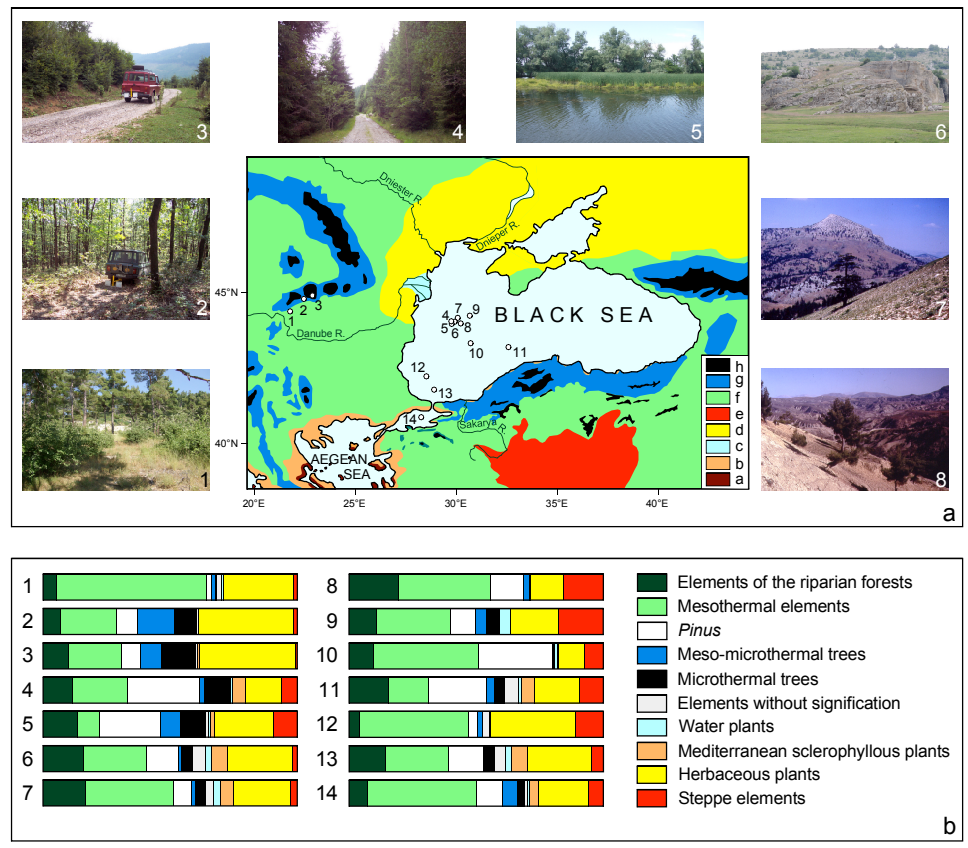

Fig. 2 Modern vegetation and pollen data.

a, Simplified regional vegetation map according to Quézel and Barbero (1985) and Ozenda and Borel (2000): a, Thermo-Mediterranean belt; b, Meso-Mediterranean belt; c, Delta aquatic vegetation; d, Open vegetation transitional to steppes; e, Anatolian steppes; f, Deciduous oak forests; g, Montane beech belt; h; Subalpine and alpine belts (fir, spruce, etc.).

1, Sclerophyllous Mediterranean oak grove in the Dardanelles Strait; 2, Deciduous oak grove and process for pollen sampling at Ciovîrnășani (locality 1); 3, Beech grove and process for pollen sampling at Cimpu lui Neag (locality 2); 4, Spruce grove at Obărșia Lotrului (locality 3); 5, Riparian forest and freshwater plants in the Danube Delta; 6, Herbaceous vegetation in the Dobrogea Region; 7, Artemisia steppe with cedar at Belkaraağaç; 8 , Pre-steppe forest with pubescent oak near Ankara.

Photographs: 1-5, CJ.-P. Suc; 6, CS.-M. Popescu; 7-8, CP. Quézel.

Localities 1-6 are in Romania, localities 7-8 in Turkey.

b, Synthetic pollen diagrams.

1, Ciovîrnășani; 2, Cimpu lui Neag; 3, Obărșia Lotrului; 4, B2KS09; 5, BL2KS28; 6, B2KS24; 7, B2KS29; 8, B2KS38; 9, BLKS9810; 10, B2KS33; 11, BL2KS32; 12, MD04-2754; 13, B2KS02; 14, C10.

Samples $1-3$ are obtained from whipping up dust (rich in pollen grains) collected on filters transported by a car (Cour, 1974); 4 - 14 are surface samples from offshore cores.

Details on sample locations and pollen contents are provided in Table 1 in Supplementary Material. 


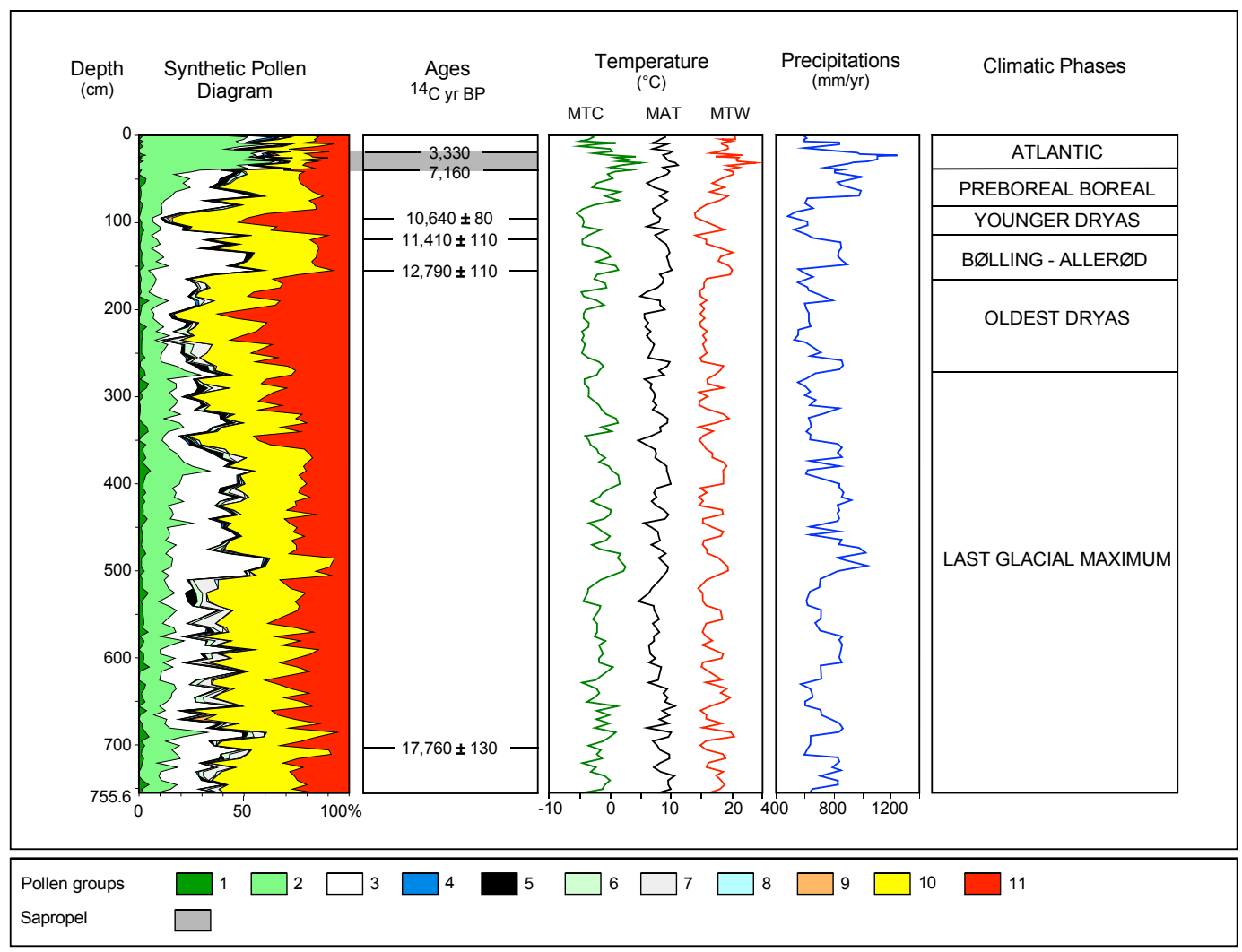

Fig. 3 Synthetic pollen diagram of core BLKS9810 with ages and quantified climatic parameters. Detailed composition of the pollen flora is provided in Table 1 in Supplementary Material.

Pollen groups: 1, Mega-mesothermal taxa; 2, Mesothermal taxa; 3, Pinus; 4, Meso-microthermal trees; 5, Microthermal trees; 6, Cupressus-Juniperus type; 7, Taxa without signification; 8, Water plants; 9, Mediterranean sclerophyllous plants; 10, Herbaceous plants; 11, Steppe taxa.

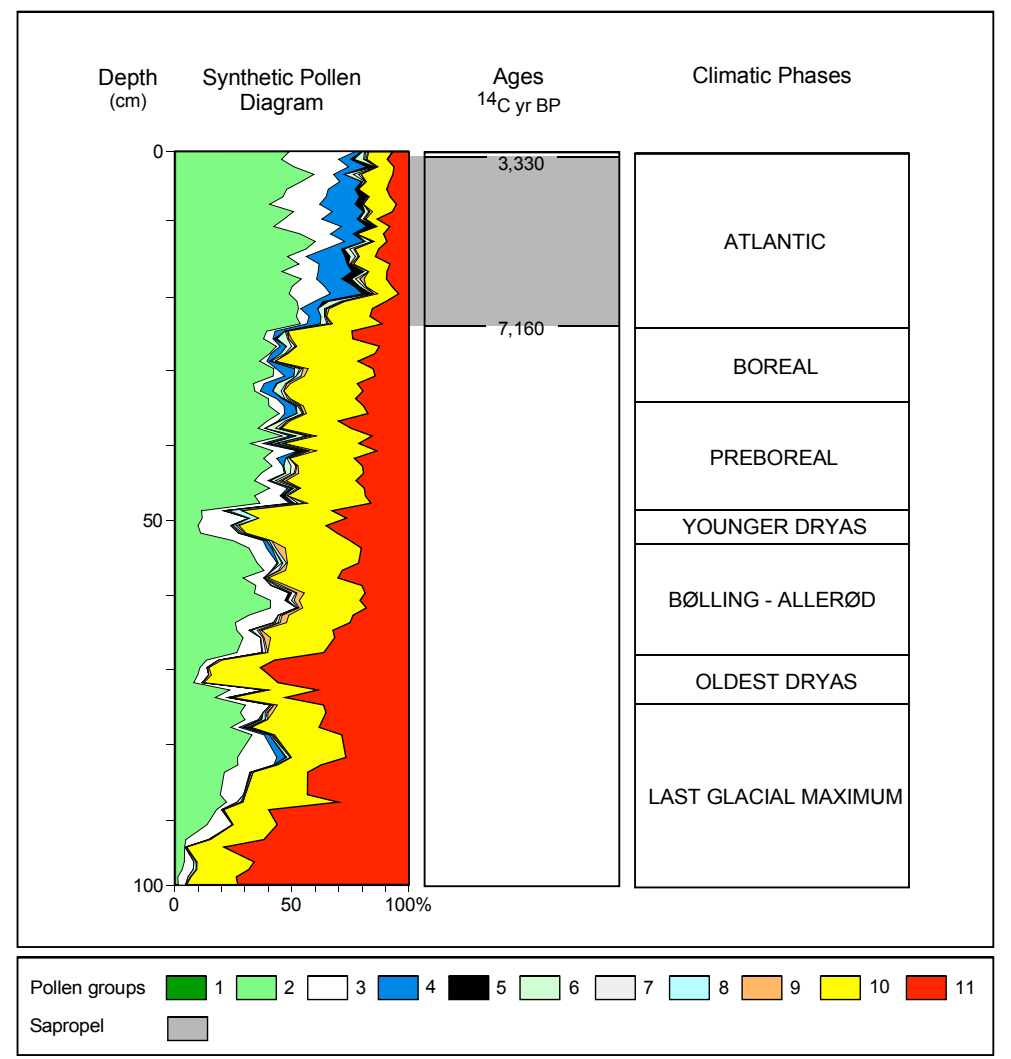

Fig. 4 Synthetic pollen diagram of core B2KS33 with ages.

Detailed composition of the pollen flora is provided in Table 2 in Supplementary Material.

Same legend as Figure 3. 


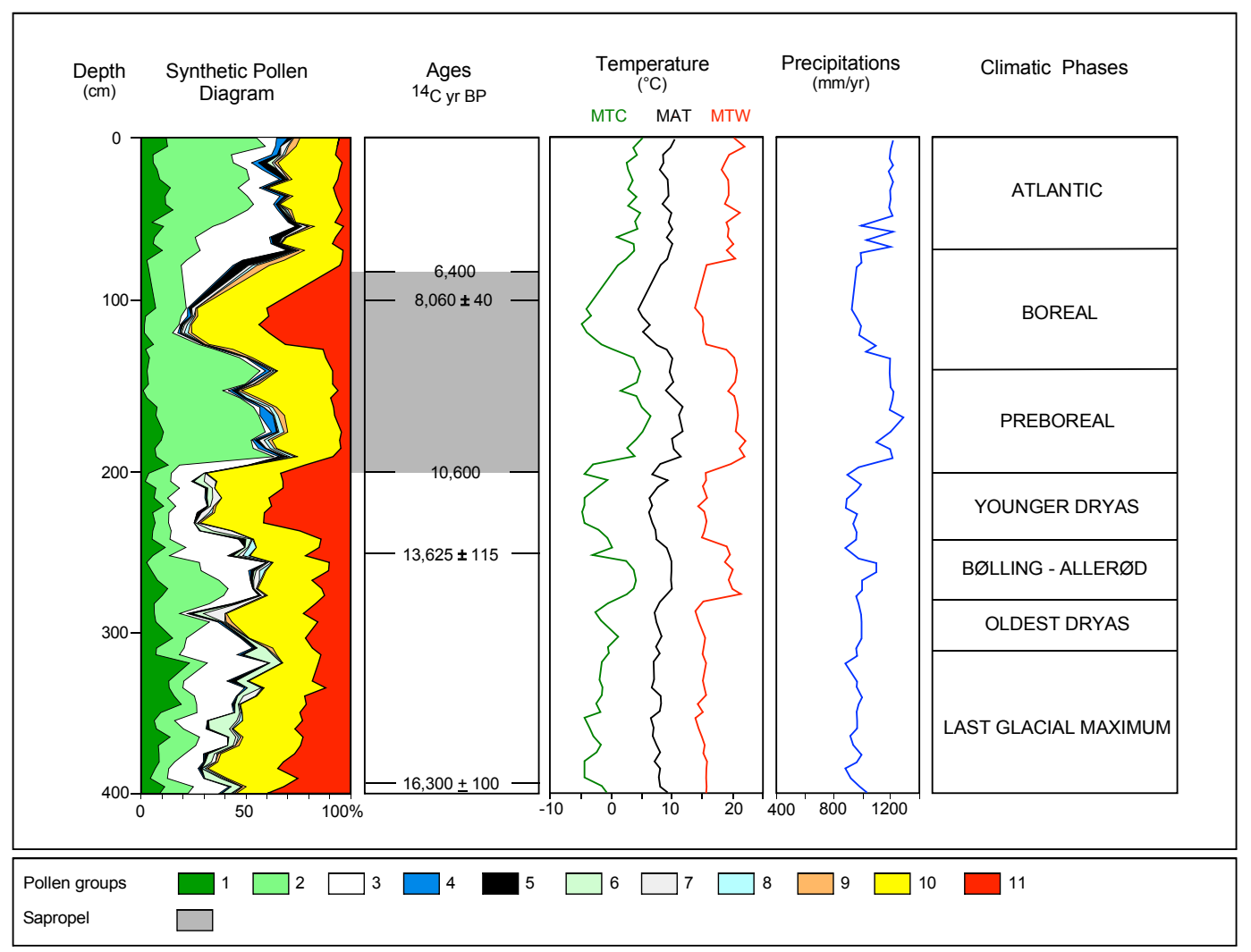

Fig. 5 Synthetic pollen diagram of core $\mathrm{C} 10$ with ages and quantified climatic parameters. Detailed composition of the pollen flora is provided in Table 3 in Supplementary Material. Same legend as Figure 3.

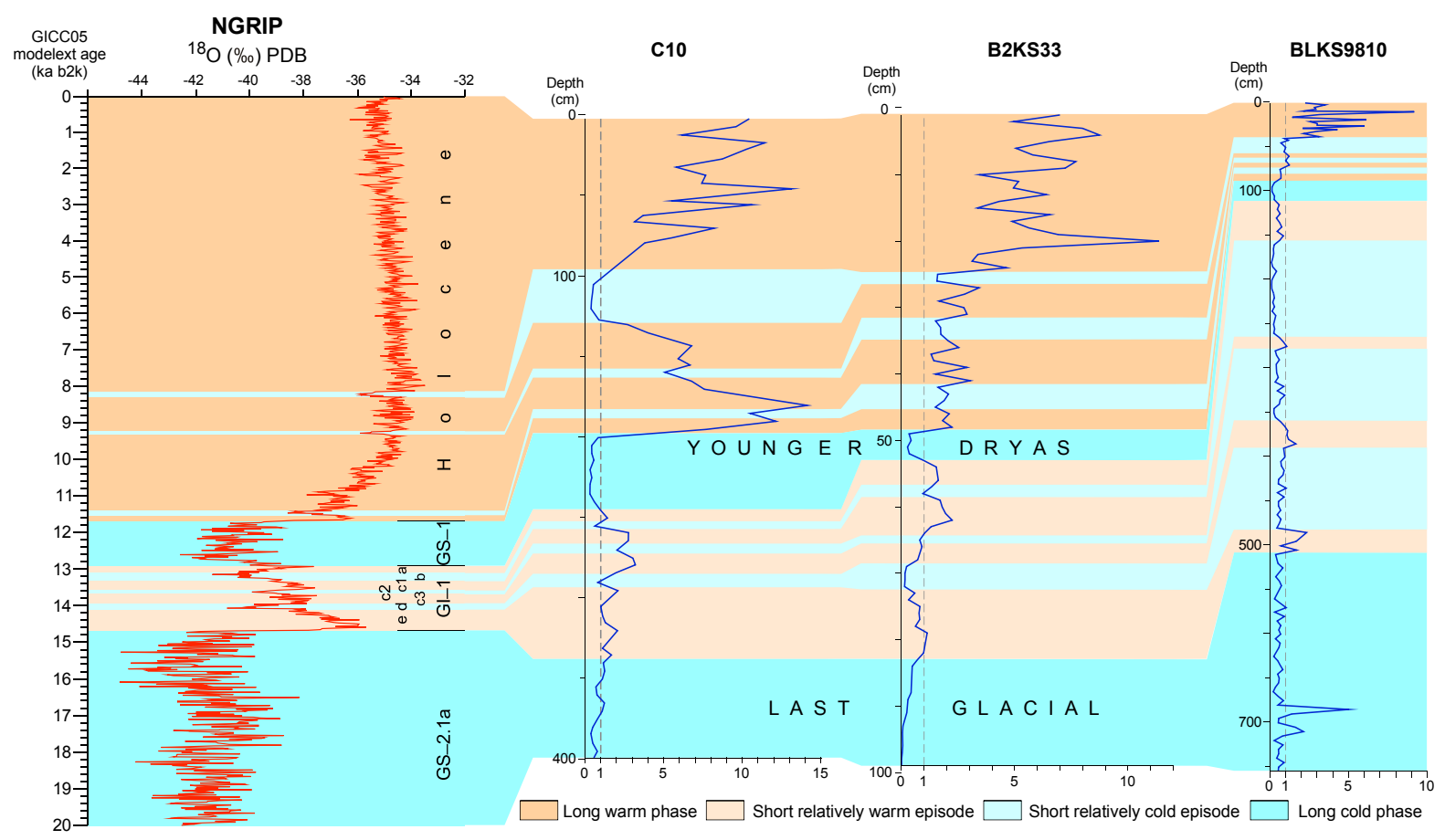

Fig. 6 Climatostratigraphic correlation of the ratio 'thermophilous/steppe taxa' (blue curves) of cores BLKS9810, B2KS33, and C10 with the NGRIP curve. 


\begin{tabular}{|l|r|r|r|}
\hline Core name & \multicolumn{1}{|c|}{ BLKS 9810 } & \multicolumn{1}{c|}{ B2KS33 } & \multicolumn{1}{c|}{ C10 } \\
\hline North latitude & $44^{\circ} 04^{\prime} 02.40^{\prime \prime}$ & $42^{\circ} 50^{\prime} 30.12^{\prime \prime}$ & $40^{\circ} 45^{\prime} 00^{\prime \prime}$ \\
\hline East longitude & $30^{\circ} 50^{\prime} 40.80^{\prime \prime}$ & $30^{\circ} 35^{\prime} 57.72^{\prime \prime}$ & $28^{\circ} 24^{\prime} 00^{\prime \prime}$ \\
\hline Water depth $(\mathrm{m})$ & 378 & 2,173 & 364 \\
\hline Cored sediment thickness $(\mathrm{cm})$ & 755.5 & 99 & 39.95 \\
\hline
\end{tabular}

Table 1 Information on location of the three analysed cores.

\begin{tabular}{|l|c|l|c|}
\hline \multicolumn{1}{|c|}{ Laboratory number } & Depth (cm) & Sample type & $\begin{array}{c}\text { AMs }{ }^{14} \mathbf{C} \text { age } \\
\text { (yr BP) } \pm 1 \sigma\end{array}$ \\
\hline BLKS9810 (Black Sea) & 94.5 & Turricaspia caspia & $10,640 \pm 80$ \\
\hline ETH-23298 & 118.5 & Dreissena rostriformis & $11,410 \pm 110$ \\
\hline ETH-23299 & 154.5 & Dreissena rostriformis & $12,790 \pm 110$ \\
\hline ETH-23300 & 186.5 & Dreissena rostriformis & $12,920 \pm 110$ \\
\hline ETH-23301 & 704 & Dreissena rostriformis & $17,760 \pm 130$ \\
\hline ETH-23302 & 92.5 & Dreissena rostriformis & $8,060 \pm 40$ \\
\hline C10 (Marmara Sea) & 247 & Dreissena rostriformis & $13,625 \pm 115$ \\
\hline OS-52727 & 386.5 & Dreissena rostriformis & $16,300 \pm 100$ \\
\hline Lyon-2810(Poz) & \multicolumn{3}{|l}{}
\end{tabular}

Table $2{ }^{14} \mathrm{C}$ ages (in yr BP) available for cores BLKS9810 and C10.

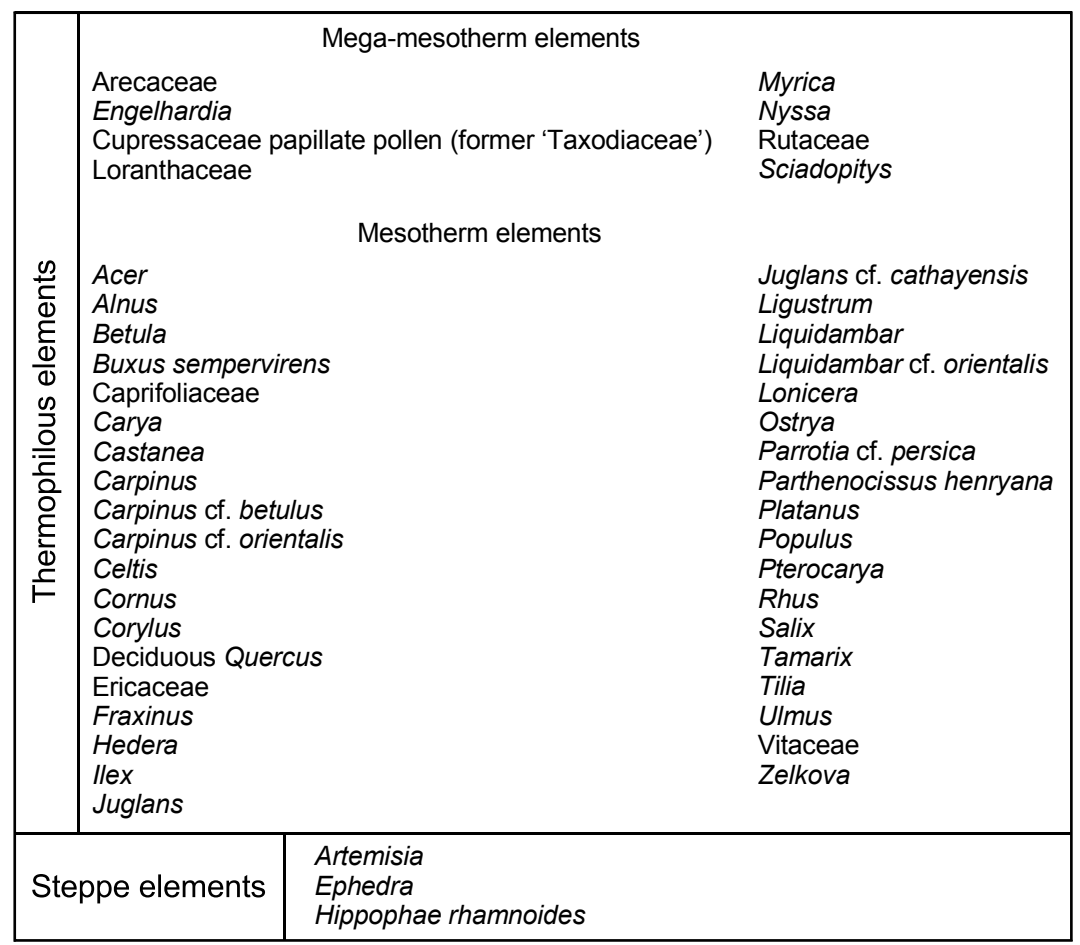

Table 3 Taxa constituting the thermophilous plants and the steppe plants. 


\begin{tabular}{|l|c|c|c|c|}
\hline Localities & MAT $\left({ }^{\circ} \mathbf{C}\right)$ & MTC $\left({ }^{\circ} \mathbf{C}\right)$ & MTW $\left({ }^{\circ} \mathbf{C}\right)$ & MAP (mm) \\
\hline İstanbul & 14.1 & 5.7 & 23.2 & 700 \\
\hline Danube Delta (Sulina) & 11 to 11.5 & -0.5 to 0.3 & 22 to 22.2 & 350 to 450 \\
\hline $\begin{array}{l}\text { Black Sea southern coast } \\
\text { (Cide) }\end{array}$ & 13 to 13.5 & 4.5 to 5 & 21.5 to 22 & 800 to 960 \\
\hline Southern Crimea (Yalta) & 11.5 to 12 & 1.5 to 2 & 22 to 22.5 & 450 to 570 \\
\hline $\begin{array}{l}\text { Northern Marmara Sea } \\
\text { (Tekirdağ) }\end{array}$ & 13.5 & 4.3 & 22.5 & 600 \\
\hline $\begin{array}{l}\text { Southern Marmara Sea } \\
\text { (Erdek) }\end{array}$ & 13.8 & 5.1 & 22.7 & 670 \\
\hline $\begin{array}{l}\text { Ciovîrnăşani } \\
\text { (elevation: } 334 \text { m) }\end{array}$ & 10.6 & -1 & 21.1 & 622 \\
\hline $\begin{array}{l}\text { Cimpu lui Neag (Uricani) } \\
\text { (elevation: } 720 \text { m) }\end{array}$ & 8.1 & -2.8 & 17.8 & 741 \\
\hline $\begin{array}{l}\text { Obărşia Lotrului (Tirici) } \\
\text { (elevation: } 1,066 \text { m) }\end{array}$ & 8.1 & -3.1 & 17.6 & 720 \\
\hline
\end{tabular}

Table 4 Present-day climate conditions (provided by https://fr.climate-data.org/) in some cities (all at elevation: $0 \mathrm{~m}$ asl.) from the regions bordering the Marmara Sea and the West Black Sea and in cities (elevation is indicated) close to the sampled localities in Romania (located in Figure 1).

MAT, mean annual temperature; MTC, mean temperature of the coldest month; MTW, mean temperature of the warmest month; MAP, mean annual precipitation. 
Supplementary Material

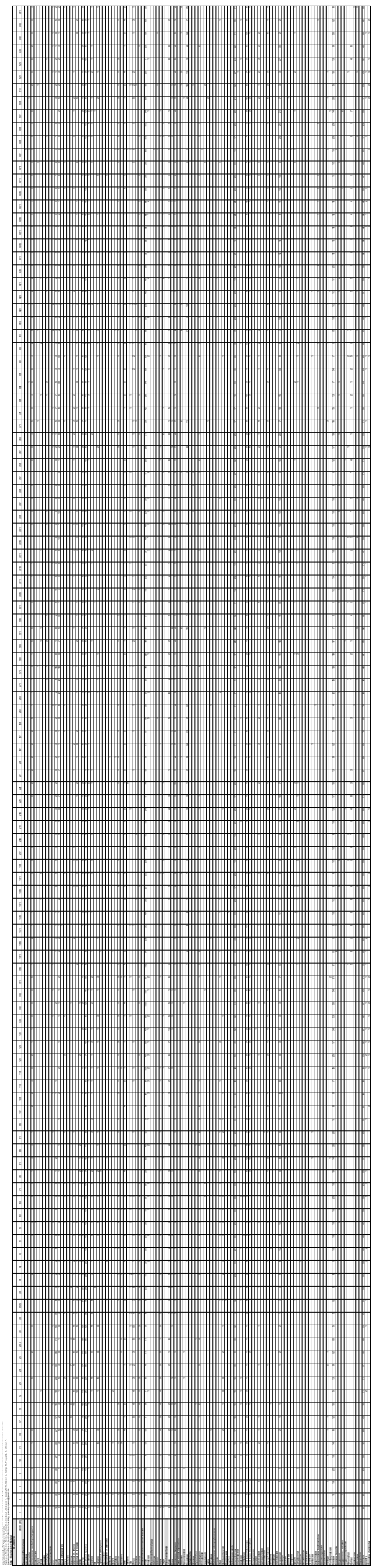

Table 1 Detailed pollen record of core BLKS9810. 


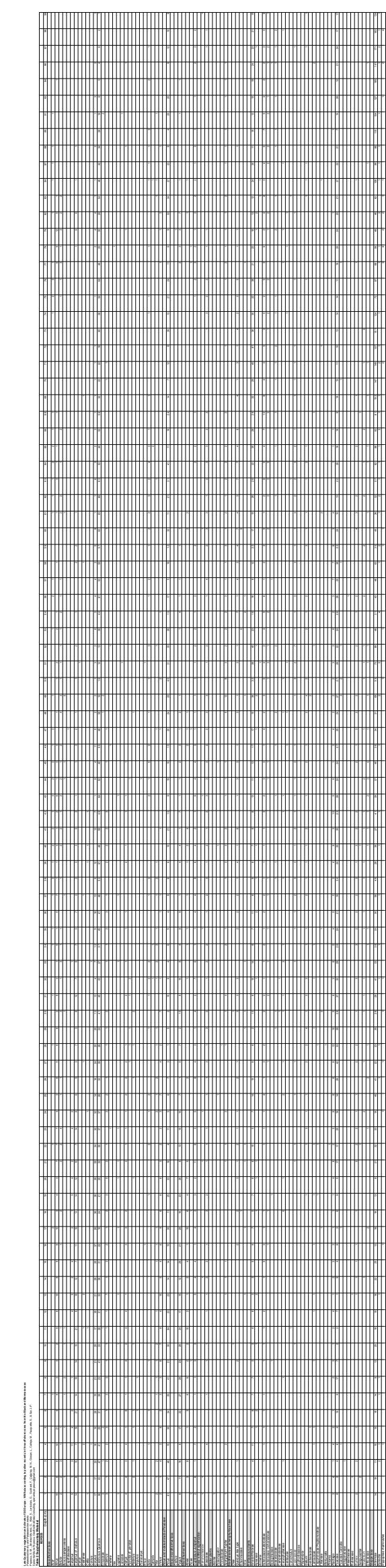

Table 2 Detailed pollen record of core B2KS33. 


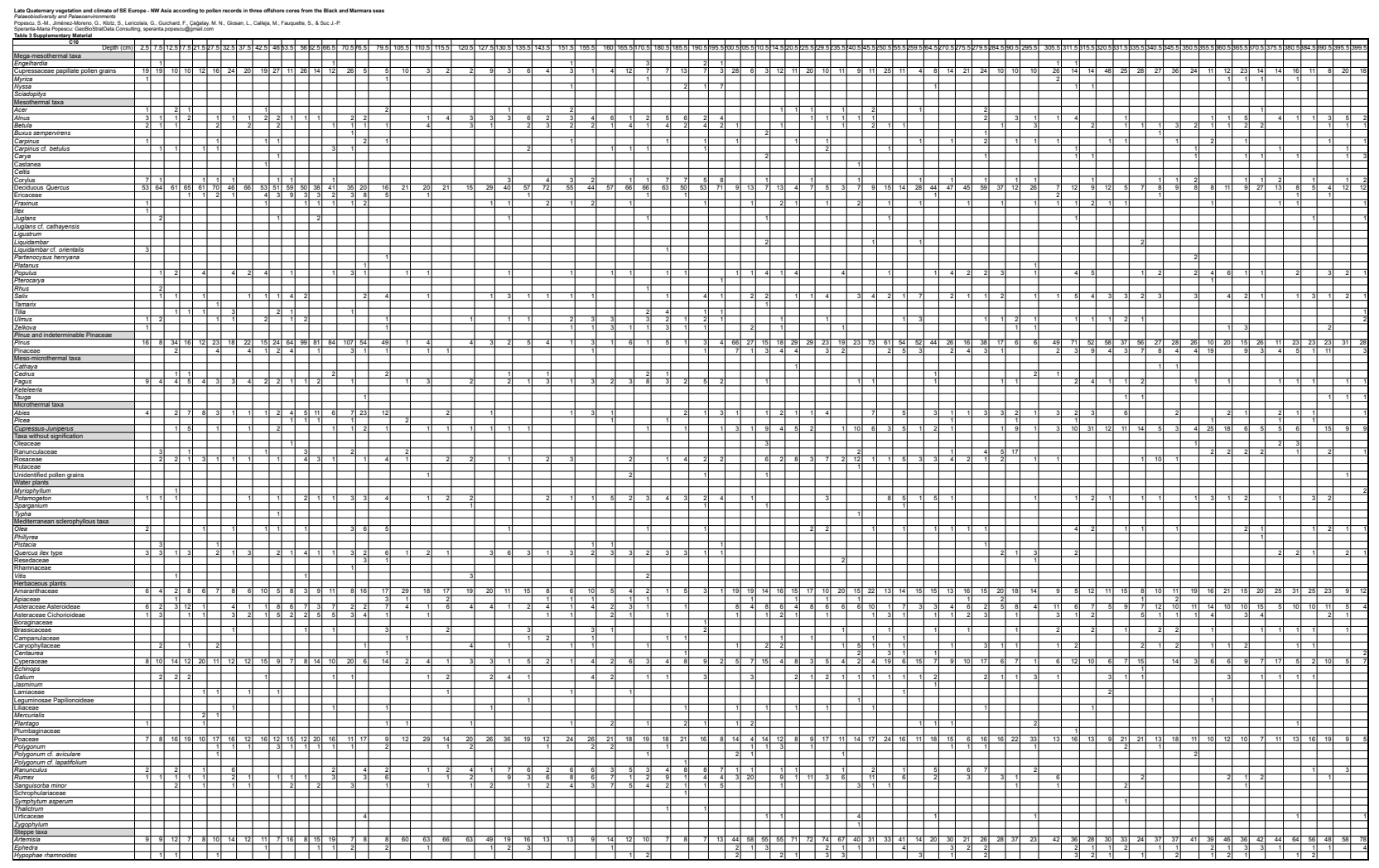

Table 3 Detailed pollen record of core C10.

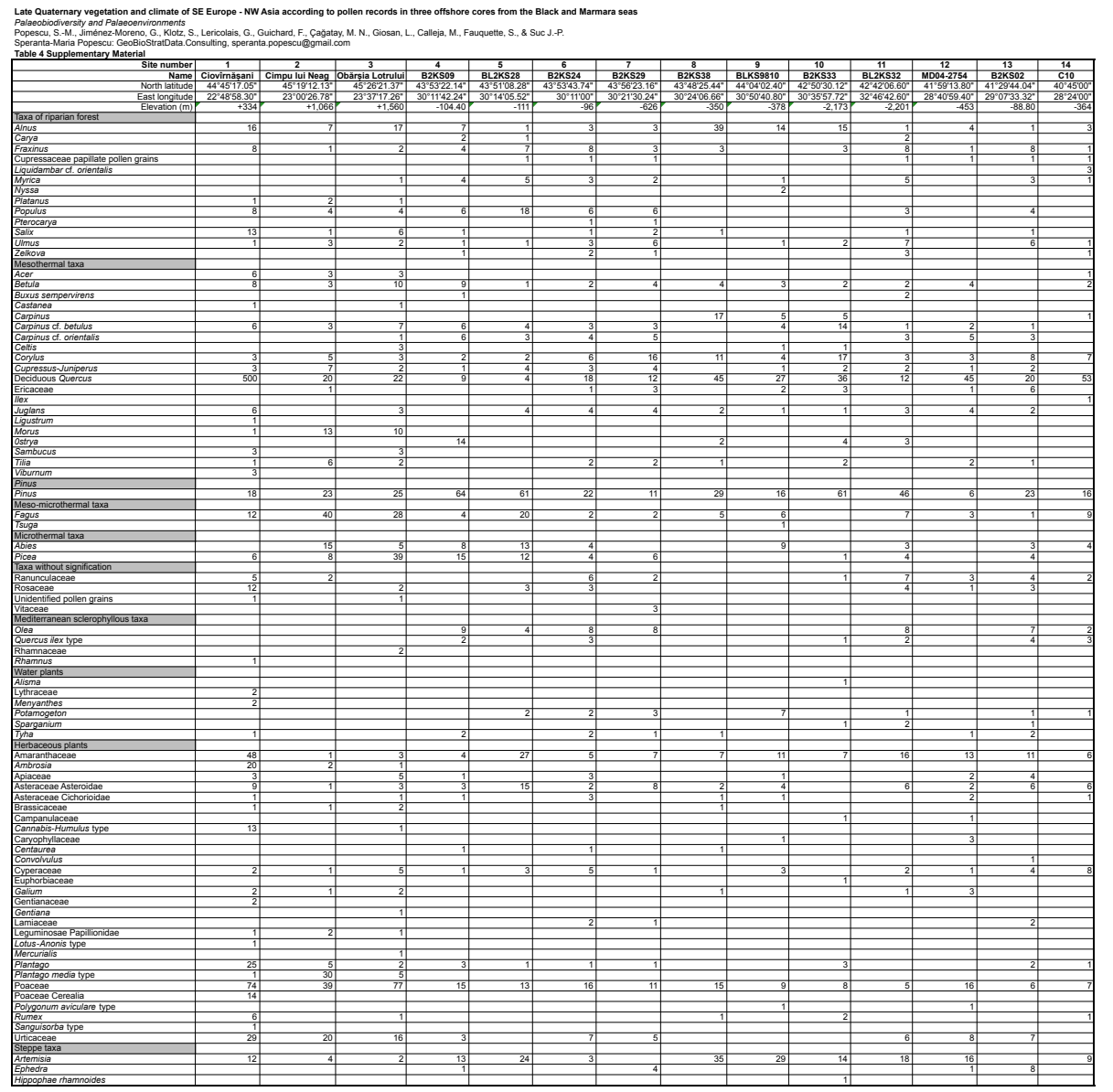

Table 4. Modern detailed pollen records: collected dust from 3 localities in the Carpathian area (South Romania) and 11 surface sediments from the Black and Marmara seas. 